\title{
Analysis of the ArcA regulon in anaerobically grown Salmonella enterica sv. Typhimurium
}

\author{
Matthew R Evans ${ }^{1,4}$, Ryan C Fink ${ }^{1,5}$, Andres Vazquez-Torres ${ }^{2}$, Steffen Porwollik ${ }^{3}$, Jessica Jones-Carson², \\ Michael McClelland ${ }^{3}$, Hosni M Hassan ${ }^{1 *}$
}

\begin{abstract}
Background: Salmonella enterica serovar Typhimurium (S. Typhimurium) is a Gram-negative pathogen that must successfully adapt to the broad fluctuations in the concentration of dissolved dioxygen encountered in the host. In Escherichia coli, ArcA (Aerobic Respiratory Control) helps the cells to sense and respond to the presence of dioxygen. The global role of ArcA in E. coli is well characterized; however, little is known about its role in anaerobically grown $S$. Typhimurium.

Results: We compared the transcriptional profiles of the virulent wild-type (WT) strain (ATCC 14028s) and its isogenic arcA mutant grown under anaerobic conditions. We found that ArcA directly or indirectly regulates 392 genes (8.5\% of the genome); of these, 138 genes are poorly characterized. Regulation by ArcA in S. Typhimurium is similar, but distinct from that in E. coli. Thus, genes/operons involved in core metabolic pathways (e.g., succinylCoA, fatty acid degradation, cytochrome oxidase complexes, flagellar biosynthesis, motility, and chemotaxis) were regulated similarly in the two organisms. However, genes/operons present in both organisms, but regulated differently by ArcA in S. Typhimurium included those coding for ethanolamine utilization, lactate transport and metabolism, and succinate dehydrogenases. Salmonella-specific genes/operons regulated by ArcA included those required for propanediol utilization, flagellar genes (mcpAC, cheV), Gifsy-1 prophage genes, and three SPI-3 genes (mgtBC, sIsA, STM3784). In agreement with our microarray data, the $\operatorname{arcA}$ mutant was non-motile, lacked flagella, and was as virulent in mice as the WT. Additionally, we identified a set of 120 genes whose regulation was shared with the anaerobic redox regulator, Fnr.

Conclusion(s): We have identified the ArcA regulon in anaerobically grown S. Typhimurium. Our results demonstrated that in S. Typhimurium, ArcA serves as a transcriptional regulator coordinating cellular metabolism, flagella biosynthesis, and motility. Furthermore, ArcA and Fnr share in the regulation of 120 S. Typhimurium genes.
\end{abstract}

\section{Background}

Salmonella enterica serovar Typhimurium (S. Typhimurium) is a Gram-negative intracellular pathogen that causes gastroenteritis in the human host. Although non life-threatening in healthy adults, it can be fatal for children and immunocompromised individuals. The infection proceeds via two main stages: invasion and systemic infection. During the invasion stage, the pathogen adheres and colonizes the intestines gaining access to the epithelial cells. Subsequently, Salmonella crosses the epithelial cells and gets internalized by the

\footnotetext{
* Correspondence: hosni_hassan@ncsu.edu

'Department of Microbiology, North Carolina State University, Raleigh, North Carolina 27695-7615 USA

Full list of author information is available at the end of the article
}

macrophages where it reproduces and stealthily spreads in the host and causes systemic infection [1-4]. Clearly, Salmonella must adapt quickly to the diverse environments it encounters. In fact, from the gastrointestinal tract to the intracellular milieu, it is challenged with fluctuations in oxygen concentration and with numerous host-immune defenses including a battery of reactive oxygen (ROS) and nitrogen species (RNS) and antimicrobial peptides that reduce its ability to colonize the host [1-4].

In Escherichia coli, ArcA (슬obic Respiratory Control) is one of the main transcriptional regulators involved in the metabolic shift from anaerobic to aerobic conditions and controlling the enzymatic defenses of bacteria against ROS. ArcA is a cytosolic response
C Biomed Central

(ㄷ) 2011 Evans et al; licensee BioMed Central Ltd. This is an Open Access article distributed under the terms of the Creative Commons Attribution License (http://creativecommons.org/licenses/by/2.0), which permits unrestricted use, distribution, and reproduction in any medium, provided the original work is properly cited. 
regulator of a two-component global regulatory system, ArcA/ArcB, where ArcB is a transmembrane histidine kinase sensor. ArcB transfers a phosphoryl group to ArcA, activating it, and inducing or repressing a large and diverse number of operons including the tricarboxylic acid cycle (TCA), terminal oxidases, dehydrogenases of the flavoprotein class, the glyoxylate shunt, and fatty acid degradation [5-17]. Due to its importance in diverse energy metabolic processes, the ArcA regulon has been thoroughly characterized in E. coli $[5,12,18]$. Conversely, very little is known about the regulatory network controlled by ArcA in $S$. Typhimurium under anaerobic conditions.

Although E. coli and S. Typhimurium share a very high genomic similarity ( 75-80\%) [19], we previously discovered that the Fnr (Fumarate Nitrate Reductase) regulon of $S$. Typhimurium is markedly different from the one identified in E. coli [20]. Due to the complementary roles of ArcA and Fnr in the regulation of cellular metabolism and adaptation to changes in redox, we hypothesized that the ArcA regulon of $S$. Typhimurium will also differ from that of $E$. coli. The results indicate that in S. Typhimurium, as in E. coli, the ArcA regulon includes the core metabolic and energy functions as well as motility. However, Salmonella-specific genes/operons regulated by ArcA include newly identified flagellar genes (mcpAC, cheV), Gifsy-1 prophage genes, a few SPI-3 genes ( $m g t B C$, sls $A$, STM3784), and those for propanediol utilization. Furthermore, the $\operatorname{arc} A$ mutant was non-motile and was as virulent as the isogenic wild-type strain. We also identified 120 genes that were regulated by the anaerobic regulator, Fnr, as well as by ArcA.

\section{Methods}

\section{Bacterial strains and growth conditions}

The bacterial strains used in this study are listed in Table 1. Wild-type (WT) S. Typhimurium (14028s) and its isogenic $\operatorname{arcA}$ mutant (NC 980) were used throughout. P22 phage was used to move the $\operatorname{arcA}:: \operatorname{Tn} 10$ mutation from $S$. Typhimurium LT2 (TT17442) [21] to strain 14028 s. Transductants were plated on Evans Blue Uranine (EBU) agar and the $\operatorname{arcA}$ mutant was tested for its inability to grow on toluidine blue agar [22]. The Tn10 insertion junctions of the $\operatorname{arcA}$ mutant were confirmed by PCR and DNA sequencing. Additionally, the absence of the ArcA protein in the mutant was confirmed by Western blotting (Additional file 1: Figure S1 - lane 3).

Unless stated otherwise, the WT and the $\operatorname{arcA}$ mutant were grown anaerobically at $37^{\circ} \mathrm{C}$ in MOPS-buffered (100 mM, pH 7.4) LB broth supplemented with $20 \mathrm{mM}$ $\mathrm{D}$-xylose (LB-MOPS-X). MOPS was used in the medium to avoid the indirect effects of $\mathrm{pH}$, while xylose was used to avoid the effects of catabolite repression [12].
An anaerobic chamber (Coy, Ann Harbor, MI) with anaerobic gas mixture $\left(10 \% \mathrm{H}_{2}, 5 \% \mathrm{CO}_{2}\right.$, and $\left.85 \% \mathrm{~N}_{2}\right)$ was used as previously described [20]. All solutions were anaerobically pre-equilibrated in the chamber for $48 \mathrm{~h}$ before use. Overnight cultures (15-18 h) were used to inoculate fresh media. Aerobic growth was carried-out using LB or LB-MOPS-X as specified (volume of the culture: flask ratio $=1: 5$, shaking at $200 \mathrm{rpm}$ using an orbital shaker). Growth kinetic experiments were performed on the WT and the $\operatorname{arcA}$ mutant in triplicate under both aerobic and anaerobic conditions.

\section{Construction of parcA}

For complementation studies, a low-copy-number plasmid, expressing $\operatorname{arcA}$ (parcA, NC 989) was constructed. The complete $\operatorname{arcA}$ sequence starting from $180 \mathrm{bp}$ upstream from the start codon (ATG) until the stop codon (TAA) of $\operatorname{arcA}$ [i.e., $897 \mathrm{bp}$ fragment] was amplified from the WT strain using the following primers (Integrated DNA Technologies, Coralville, IA):

$\operatorname{arcA-Forward~5'-~TCGATCCCGGGTACCCACGAC~}$ CAAGCTAATG-3' and arcA-Reverse 5'-CTACCT CCCGGGTTAATCCTGCAGGTCGCCG -3' [SmaI site underlined]. The PCR product was digested with SmaI and ligated into the pACYC177 (New England BioLabs, Ipswich, MA) vector that was also cut with SmaI. Thus, in the new plasmid (parcA) the $\mathrm{Kan}^{\mathrm{r}}$ gene in pACYC177 was disrupted by the insertion of $\operatorname{arcA}$. Plasmid DNA (parcA) was first transformed into a restriction deficient strain of E. coli [ER2925 (New England BioLabs)], which was subsequently purified and transformed into and maintained in the $S$. Typhimurium $\operatorname{arc} A$ mutant, thus generating NC989 (Table 1).

Transformations were carried-out using the calcium chloride method [23]. Plasmid DNA and genomic DNA were isolated using the Qiagen Mini Spin isolation kit (Qiagen, Valencia, CA) and the DNAeasy Tissue Kit (Qiagen), respectively. Transformants containing parcA (NC989) were confirmed for $\mathrm{Amp}^{\mathrm{r}}(130 \mu \mathrm{g} / \mathrm{ml})$ and $\mathrm{Kan}^{\mathrm{s}}(50 \mu \mathrm{g} / \mathrm{ml})$ on LB plates and the presence of parcA was confirmed via PCR and restriction analysis. The expression of ArcA was confirmed by Western blot analysis (Additional file 1: Figure S1 - lane 4).

\section{RNA isolation}

Overnight anaerobic cultures of the WT or the $\operatorname{arcA}$ mutant were used to inoculate three independent flasks for each strain. Every flask contained $150 \mathrm{ml}$ of LBMOPS-X equilibrated in the anaerobic gas mix for the previous $48 \mathrm{~h}$. The three independent cultures of each strain were grown to an $\mathrm{OD}_{600}=0.30-0.35$, pooled, and treated with RNAlater (Qiagen, Valencia, CA) to fix the cells and preserve the quality of the RNA. Total RNA was extracted using RNeasy RNA extraction kit (Qiagen) 
Table 1 List of strains, plasmids, and phage used in this study

\begin{tabular}{|c|c|c|}
\hline $\begin{array}{l}\text { Strain, Plasmid, } \\
\text { or Phage }\end{array}$ & Relevant Characteristics & $\begin{array}{l}\text { Source and/or } \\
\text { Reference }\end{array}$ \\
\hline \multicolumn{3}{|l|}{ Strains } \\
\hline \multicolumn{3}{|l|}{$\begin{array}{l}\text { Salmonella } \\
\text { Typhimurium }\end{array}$} \\
\hline $14028 \mathrm{~s}$ & Wild-type & $\begin{array}{l}\text { American Type Culture } \\
\text { Collection }\end{array}$ \\
\hline $\begin{array}{l}\text { TT17442/ } \\
\text { SL3052 }\end{array}$ & (LT2) containing metE205 ara-9 cob-24::MudJ arcA201::Tn10d-Tet & [21/S. Libby] \\
\hline NC980 & 14028 s containing $\operatorname{arcA::Tn} 10\left(\right.$ Tet' $\left.^{\prime}\right)$ [T117442 $\left.\left(\mathrm{P}_{22}\right) \times 14028 \mathrm{~s}\right]$ & This study \\
\hline NC989 & Same as NC980, but harboring parcA. & This study \\
\hline \multicolumn{3}{|l|}{ Escherichia coli } \\
\hline ER2420 & Harboring pACYC177 & New England Biolabs \\
\hline ER2925 & 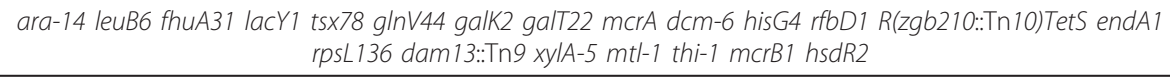 & New England Biolabs \\
\hline \multicolumn{3}{|l|}{ Plasmids } \\
\hline pACYC177 & $\mathrm{F}^{-}$ara-14 leu fhuA2 $\Delta\left(\mathrm{gpt}\right.$-proA)62 lacY1 glnV44 galK2 rpsL20 xyl-5 mtl-1 $\Delta(\mathrm{mcrC}-\mathrm{mrr})_{\mathrm{HB} 101}$ & New England Biolabs \\
\hline parcA & $\begin{array}{l}\text { An } 897 \text { base pair arcA amplicon from S. Typhimurium } 14028 \text { s cloned into the Smal site within the } \\
\text { Kan' gene of pACYC177. }\end{array}$ & This study \\
\hline \multicolumn{3}{|l|}{ Phage } \\
\hline P22 & & $\begin{array}{l}\text { S. Libby/Collection } \\
\text { stock of NC }\end{array}$ \\
\hline
\end{tabular}

and the samples were treated with RNase-free DNase (Invitrogen, Carlsbad, CA). The absence of contaminating DNA and the quality of the RNA was confirmed by the lack of PCR amplification of known genes (i.e.: fnr) and by using agarose-gel electrophoresis. Aliquots of the RNA samples were kept at $-80^{\circ} \mathrm{C}$ for use in the microarray and the qRT-PCR studies.

\section{Microarray studies}

$S$. Typhimurium microarray slides were prepared and used as previously described [24]. For the hybridizations, the SuperScript ${ }^{\mathrm{TM}}$ Indirect cDNA Labeling System (Invitrogen) was used to synthesize the cDNA from the RNA prepared from the WT and $\operatorname{arcA}$ mutant strains. Dye swapping was performed to avoid dye-associated effects on cDNA synthesis. Slide hybridizations and scanning were carried-out using the same protocols and equipment as previously described [20].

\section{Data analysis}

Cy3 and Cy5 values for each spot were normalized over the total intensity for each dye, to account for differences in total intensity between the two scanned images. The consistency of the data obtained from the microarray analysis was evaluated using two methods: (i) a pair-wise comparison, calculated with a two-tailed Student's $t$ test and analyzed by the MEAN and TTEST procedures of
SAS-STAT statistical software (SAS Institute, Cary, NC) [the effective degrees of freedom for the $t$ test were calculated as previously described [25]; and (ii) a regularized $t$ test followed by a posterior probability of differential expression [PPDE (p)] method. The signal intensity at each spot from the $\operatorname{arc} A$ mutant and the WT were background-subtracted, normalized, and used to calculate the ratio of gene expression between the two strains. All replicas were combined and the median expression ratio and standard deviations calculated for ORFs showing $\geq$ 2.5-fold change.

\section{Microarray data}

The microarray data are accessible via GEO Accession Number GSE24564 at http://www.ncbi.nlm.nih.gov/geo/ query/acc.cgi?acc=GSE24564.

\section{qRT-PCR}

qRT-PCR [26] was used to validate the microarray data [27]. Seventeen genes were randomly chosen (Table 2) from the differentially expressed genes. Primers (Integrated DNA Technologies, Coralville, IA) were designed and qRT-PCRs were carried-out using QuantiTectTM SYBR $^{\circledR}$ Green RT-PCR Kit (Qiagen), an iCycler ${ }^{\mathrm{TM}}$ (BioRad, Hercules, CA), and the data were analyzed by the Bio-Rad Optical System Software - Version 3.1, according to the manufacturer specifications. The cycling 
Table 2 Validation of microarray data using qRT-PCR of randomly selected genes relative to the housekeeping gene, rpo $D^{a}$

\begin{tabular}{|c|c|c|c|c|c|c|c|c|}
\hline \multirow[t]{2}{*}{ Locus $^{b}$} & \multirow[t]{2}{*}{ Name $^{c}$} & \multirow[t]{2}{*}{ Primer sequence $^{d}$} & \multirow[t]{2}{*}{$\begin{array}{l}\text { Fragment } \\
(\mathrm{bp})^{\mathrm{e}}\end{array}$} & \multirow[t]{2}{*}{$\begin{array}{c}\text { Serovar Typhimurium Gene } \\
\text { Function }^{f}\end{array}$} & \multicolumn{2}{|c|}{$\begin{array}{l}\text { Ratio of } \operatorname{arcA} \\
\text { mutant/WT }\end{array}$} & \multicolumn{2}{|c|}{$\log _{2}$ ratio } \\
\hline & & & & & $\begin{array}{l}\text { qRT- } \\
\text { PCR }^{g}\end{array}$ & Microarray $^{h}$ & $\begin{array}{l}\text { qRT- } \\
\text { PCR }^{\mathrm{i}}\end{array}$ & Microarray ${ }^{j}$ \\
\hline STM3217 & aer & $\begin{array}{l}\text { 5'-CGTACAACATCTTAATCGTAGC-3' } \\
\text { 5'-TTCGTTCAGATCATTATTACCC-3' }\end{array}$ & 163 & $\begin{array}{c}\text { aerotaxis sensor receptor, senses } \\
\text { cellular redox state or proton } \\
\text { motive force }\end{array}$ & 0.237 & 0.293 & -2.1 & -1.8 \\
\hline STM1919 & cheM & $\begin{array}{c}\text { 5'-GCCAATTTCAAAAATATGACG-3' } \\
\text { 5'-GTCCAGAAACTGAATAAGTTCG-3' }\end{array}$ & 114 & $\begin{array}{c}\text { methyl accepting chemotaxis } \\
\text { protein II, aspartate sensor- } \\
\text { receptor }\end{array}$ & 0.194 & 0.261 & -2.4 & -1.9 \\
\hline STM0441 & cyoC & $\begin{array}{l}\text { 5'-TATTTAGCTCCATTACCTACGG-3' } \\
\text { 5'-GGAATTCATAGAGTTCCATCC-3' }\end{array}$ & 134 & $\begin{array}{c}\text { cytochrome o ubiquinol oxidase } \\
\text { subunit III }\end{array}$ & 4.920 & 5.465 & 2.3 & 2.5 \\
\hline STM1803 & $\operatorname{dad} A$ & $\begin{array}{l}\text { 5'-TAACCTTTCGCTTTAATACTCC-3' } \\
\text { 5'-GATATCAACAATGCCTITAAGC-3' }\end{array}$ & 155 & $\begin{array}{c}\text { D-amino acid dehydrogenase } \\
\text { subunit }\end{array}$ & 3.430 & 10.520 & 1.8 & 3.4 \\
\hline STM2892 & inv & $\begin{array}{l}\text { 5'-TTGCTATCGTCTAAAAATAGGC-3' } \\
\text { 5'-TTGATATTATCGTCAGAGATTCC-3' }\end{array}$ & 128 & $\begin{array}{l}\text { surface presentation of antigens; } \\
\text { secretory proteins }\end{array}$ & 0.855 & 1.010 & -0.2 & 0.0 \\
\hline STM2324 & nuof & $\begin{array}{c}\text { 5'-GGATATCGAGACACTTGAGC-3' } \\
\text { 5'-GATTAAATGGGTATTACTGAACG-3' }\end{array}$ & 163 & NADH dehydrogenase I chain F & 0.380 & 1.706 & -1.4 & 0.8 \\
\hline STM0650 & STM0650 & $\begin{array}{c}\text { 5'-CAACAGCTTATTGATTTAGTGG-3' } \\
\text { 5'-CTAACGATTITTCTTCAATGG-3' }\end{array}$ & 130 & putative hydrolase C-terminus & 0.274 & 0.123 & -1.9 & -3.0 \\
\hline STM2787 & STM2787 & $\begin{array}{c}\text { 5'-AAGCGAATACAGCTATGAACC-3' } \\
\text { 5'-ATTAGCTITTGCAGAACATGG-3' }\end{array}$ & 144 & tricarboxylic transport & 6.440 & 90.770 & 2.7 & 6.5 \\
\hline STM4463 & STM4463 & $\begin{array}{c}\text { 5'-AAGGTATCAGCCAGTCTACG-3' } \\
\text { 5'-CGTATGGATAAGGATAAATTCG-3' }\end{array}$ & 142 & putative arginine repressor & 0.165 & 0.012 & -2.6 & -6.4 \\
\hline STM2464 & eutN & $\begin{array}{l}\text { 5'-AGGACAAATCGTATGTACCG-3' } \\
\text { 5'-ACCAGCAGTACCCACTCTCC-3' }\end{array}$ & 153 & $\begin{array}{l}\text { putative detox protein in } \\
\text { ethanolamine utilization }\end{array}$ & 0.181 & 0.159 & -2.5 & -2.7 \\
\hline STM2454 & eutR & $\begin{array}{l}\text { 5'-GGTAAAAGAGCAGCATAAAGC-3' } \\
\text { 5'-ATTATCACTCAAGACCTTACGC-3' }\end{array}$ & 118 & $\begin{array}{c}\text { putative regulator ethanolamine } \\
\text { operon (AraC/XylS family) }\end{array}$ & 0.189 & 0.188 & -2.4 & -2.4 \\
\hline STM2470 & euts & $\begin{array}{l}\text { 5'-AATAAAGAACGCATTATTCAGG-3' } \\
\text { 5'-GTTAAAGTCATAATGCCAATCG-3' }\end{array}$ & 137 & $\begin{array}{l}\text { putative carboxysome structural } \\
\text { protein, ethanol utilization }\end{array}$ & 0.197 & 0.105 & -2.3 & -3.3 \\
\hline STM1172 & $f \lg M$ & $\begin{array}{l}\text { 5'-AGCGACATTAATATGGAACG-3' } \\
\text { 5'-TITACTCTGTAAGTAGCTCTGC-3' }\end{array}$ & 126 & $\begin{array}{l}\text { anti-FliA (anti-sigma) factor; also } \\
\text { known as RflB protein }\end{array}$ & 0.196 & 0.163 & -2.4 & -2.6 \\
\hline STM3692 & $\| d P$ & $\begin{array}{l}\text { 5'-TGATTAAACTCAAGCTGAAAGG-3' } \\
\text { 5'-CCGAAATITIATAGACAAAGACC-3' }\end{array}$ & 189 & $\begin{array}{l}\text { LctP transporter, L-lactate } \\
\text { permease }\end{array}$ & 5.950 & 12.780 & 2.6 & 3.7 \\
\hline STM3693 & $\| d R$ & $\begin{array}{l}\text { 5'-GAACAGAATATCGTGCAACC-3' } \\
\text { 5'-GAGTCTGATITCTCTITGTCG-3' }\end{array}$ & 153 & $\begin{array}{l}\text { putative transcriptional regulator } \\
\text { for Ict operon (GntR family) }\end{array}$ & 5.750 & 80.000 & 2.5 & 6.3 \\
\hline STM1923 & motA & $\begin{array}{l}\text { 5'-GGTTATCGGTACAGTITCG-3' } \\
\text { 5'-TAGATIITGTGTATITCGAACG-3' }\end{array}$ & 194 & $\begin{array}{l}\text { proton conductor component of } \\
\text { motor, torque generator }\end{array}$ & 0.282 & 0.253 & -1.8 & -2.0 \\
\hline STM4277 & nrfa & $\begin{array}{c}\text { 5'-GACTAACTCTCTGTCGAAAACC-3' } \\
\text { 5'-ATTITATGGTCGGTGTAGAGC-3' }\end{array}$ & 159 & $\begin{array}{l}\text { nitrite reductase periplasmic } \\
\quad \text { cytochrome } c(552)\end{array}$ & 0.314 & 0.285 & -1.7 & -1.8 \\
\hline
\end{tabular}

${ }^{\mathrm{a}} \mathrm{STM} 3211(\mathrm{rpoD})$ is a housekeeping gene that was used as the reference gene where no significant

change in expression level was observed. The primer sequences ( $5^{\prime}$ to $\left.3^{\prime}\right)$ used for $r p o D$ were as follows: CGATGTCTCTGAAGAAGTGC (forward) and

TTCAACCATCTCTITCTTCG (reverse). The size of the fragment generated is $150 \mathrm{bp}$.

${ }^{b}$ Location of the open reading frame (ORF) in the S. Typhimurium LT2 genome.

${ }^{\mathrm{c}}$ Respective gene name or symbol.

${ }^{d}$ For each set, the first primer is the forward primer and the second primer is the reverse primer.

'Size of the amplified PCR product.

${ }^{f}$ Functional classification according to the KEGG (Kyoto Encyclopedia of Genes and Genomes) database.

${ }^{g}$ Expression levels of quantitative reverse transcriptase polymerase chain reaction - values shown as the ratio between the arcA mutant and the wild-type; where values $<1$ indicate that ArcA acts as an activator, and values $>1$ indicate ArcA acts as a repressor.

${ }^{h}$ Expression levels from the microarray data - values shown as the ratio between the $\operatorname{arcA}$ mutant and the wild-type; where values $<1$ indicate that ArcA acts as an activator, and values $>1$ indicate ArcA acts as a repressor.

'Expression levels of quantitative reverse transcriptase polymerase chain reaction comparing the $\operatorname{arcA}$ mutant versus the wild-type - shown in signal to log 2 ratio (SLR).

${ }^{j}$ Expression levels of microarray data comparing the $\operatorname{arcA}$ mutant versus the wild-type - shown in signal to $\log _{2}$ ratio (SLR). 
conditions comprised $30 \mathrm{~min}$ of a reverse transcriptase reaction at $50^{\circ} \mathrm{C}, 15 \mathrm{~min}$ of polymerase inactivation at $95^{\circ} \mathrm{C}$, and 40 cycles each of $94^{\circ} \mathrm{C}$ for $15 \mathrm{sec}$ for melting, $51^{\circ} \mathrm{C}$ for $30 \mathrm{sec}$ for annealing, and $72^{\circ} \mathrm{C}$ for $30 \mathrm{sec}$ for extension followed by 31 cycles each at $65^{\circ} \mathrm{C}$ for $10 \mathrm{sec}$ to obtain the melt curve. To ensure accurate quantification of the mRNA levels, three amplifications of each gene were made using 1:5:25 dilutions of the total RNA. Measured mRNA levels were normalized to the mRNA levels of the housekeeping gene, rpoD $\left(\sigma^{70}\right)$. Normalized values were used to calculate the ratios of the expression levels [20] in the $\operatorname{arcA}$ mutant relative to the WT.

\section{Logo graph and promoter analysis}

The information matrix for the generation of the ArcA logo was produced using the alignment of the E. coli ArcA binding sequences, available at http://arep.med. harvard.edu/ecoli_matrices/[28]. The alignment of the ArcA motifs from this website did not include the motifs present in the sodA and mutM promoters $[29,30]$, therefore they were included in our analysis. To account for differences in nucleotide usage or slight variations in consensus sequences, a second alignment was built for $S$. Typhimurium using the 5'-regions of the homologous genes originally used to build the $E$. coli information matrix. The Salmonella alignment was used to prepare a new information matrice using the Patser software (version 3d), available at http://rsat.ulb.ac.be/ rsat/[31] and graphed using the Weblogo software (version 2.8.1, 2004-10-18), available at http://weblogo. berkeley.edu/[32].

\section{Swarming motility assay and electron microscopy}

The swarming of the WT and the $\operatorname{arcA}$ mutant were evaluated under anoxic conditions. Ten microliters of anaerobically grown cells (i.e., from $16 \mathrm{~h}$ cultures) were spotted onto LB-MOPS-X agar (0.6\% agar) plates and incubated anaerobically at $37^{\circ} \mathrm{C}$ for $24 \mathrm{~h}$. The diameter of the growth halo was used as a measure of swarming. Scanning electron microscopy (SEM) was used to examine the morphology of the extracellular surfaces, while transmission electron microscopy (TEM) and negative staining were used to visualize the flagella of the anaerobically grown WT and $\operatorname{arcA}$ mutant as previously described [20].

\section{Pathogenicity studies}

For single infectionassays, six to eight week old female C57BL/6 mice bred in the University of Colorado School of Medicine animal facility according to Institutional Animal Care and Use Committee guidelines were used in this study. WT and $\operatorname{arcA}$ mutant Salmonella were grown in LB-MOPS-X broth to stationary phase for about 20 h. For intraperitoneal (i.p.) challenge, two groups of five mice per strain (WT and $\operatorname{arc} A$ mutant) were inoculated with $250 \mathrm{CFU}$ in $500 \mu \mathrm{l} \mathrm{PBS} /$ mouse. Mortality was scored over a 15- to 30-day period. Competitive infection assays were carried-out as described [33] with modifications. The strains were separately grown overnight in LB broth at $37^{\circ} \mathrm{C}$ with shaking at $200 \mathrm{rpm}$. Tetracycline $(10 \mu \mathrm{g} / \mathrm{ml})$ was used to propagate and isolate the $\operatorname{arcA}$ mutant. Bacterial (i. e.: WT and $\operatorname{arc} A$ mutant) cultures were diluted in phosphatebuffered saline (PBS) and mixed to produce a 1:1 inoculum ratio. Groups of mice were infected either i.p. or orally (p.o.). Prior to oral infection, food and water were withheld from the mice for $4 \mathrm{~h}$ and the bacterial cocktail was administered to the mice by allowing them to drink $20 \mu \mathrm{l}$ from the end of a pipette tip.

On day 4 or day 6 after i.p. or p.o. infection, respectively, mice were euthanized and mesenteric lymph nodes (MLN), liver and spleen collected for bacterial enumeration. The tissues were homogenized in sterile PBS and 10-fold serial dilutions were plated on LB agar medium with or without $10 \mu \mathrm{g} / \mathrm{mL}$ tetracycline to distinguish the WT $\left(\mathrm{Tet}^{\mathrm{s}}\right)$ from the $\operatorname{arc} A$ mutant $\left(\mathrm{Tet}^{\mathrm{r}}\right)$. The number of CFUs of $S$. Typhimurium 14028 s per organ was calculated by subtracting the number of $\mathrm{CFU} / \mathrm{ml}$ on the LB-Tet plates from the number of CFU/ $\mathrm{ml}$ on the corresponding LB plates. The competitive index (CI) was calculated as the ratio of the CFU of $\operatorname{arcA}$ mutant to the CFU of the WT strain recovered from the spleen, liver, and mesenteric lymph nodes (i.e.; $\left.\mathrm{CI}=[\operatorname{arc} A \text { mutant } / \mathrm{WT}]_{\text {output }} /[\operatorname{arc} A \text { mutant } / \mathrm{WT}]_{\text {input }}\right)$.

\section{Results}

Bacterial growth kinetics

The growth kinetics of the WT and the $\operatorname{arcA}$ mutant strains were determined under anaerobic conditions in LB-MOPS-X. The $\operatorname{arc} A$ mutant strain grew at a slower rate than the WT strain. The doubling-times of the WT and $\operatorname{arc} A$ mutant were $37.0 \pm 0.4$ and $55.4 \pm 0.1 \mathrm{~min}$ under anaerobic conditions. Due to the difference in the doubling-times of the two strains, cells used for RNA isolation and subsequent transcriptome profiling were allowed to grow for an equal number of generations ( five generations: $\left.\mathrm{OD}_{600}=0.30-0.35\right)$ instead of an equal length of time.

\section{Anaerobic transcriptome profiling}

Out of 4,579 genes, the two-tailed Student's $t$ test, produced a set of 2,026 coding sequences showing a significant difference between the $\operatorname{arcA}$ mutant and the WT $(\mathrm{p}<0.05)$. We restricted the analyses to only include highly affected genes (i.e., has a ratio $\geq 2.5$-fold) as previously described [20]. Under this constraint, 392 genes were differentially expressed in the $\operatorname{arc} A$ mutant relative to the WT and, therefore, regulated directly or indirectly 
by ArcA. Of these, 147 genes were up-regulated and 245 genes were down-regulated (Additional file 1: Table S1). All the genes showing significant differential expression were classified into clusters of orthologous groups (COGs) [34-36] as defined by the National Center for Biotechnology Information (NCBI) http://www.ncbi.nlm. nih.gov/COG (Table 3). It should be noted that throughout the study we compared the levels of transcription in the $\operatorname{arcA}$ mutant to that in the WT strain. Thus, genes repressed by ArcA posses positive values

Table 3 Classification of ArcA regulated genes according to Clusters of Orthologous Groups (COGs)

\begin{tabular}{|c|c|c|}
\hline \multirow[t]{2}{*}{ Functional Gene Groups ${ }^{a}$} & \multicolumn{2}{|c|}{ \# of Genes ${ }^{b}$} \\
\hline & $\begin{array}{c}\text { ArcA- } \\
\text { activated }\end{array}$ & $\begin{array}{l}\text { ArcA- } \\
\text { repressed }\end{array}$ \\
\hline Cell division and chromosome partitioning & 0 & 0 \\
\hline $\begin{array}{l}\text { Cell envelope and biogenesis, outer } \\
\text { membrane }\end{array}$ & 4 & 4 \\
\hline Cell motility and secretion & 1 & 12 \\
\hline $\begin{array}{l}\text { Posttranslational modification, protein } \\
\text { turnover, chaperones }\end{array}$ & 1 & 3 \\
\hline Inorganic ion transport and metabolism & 1 & 12 \\
\hline Signal transduction mechanisms & 5 & 3 \\
\hline Cellular processes ${ }^{c}$ & 12 & 34 \\
\hline Defense Mechanisms ${ }^{c}$ & 1 & 1 \\
\hline $\begin{array}{c}\text { Translation, ribosomal structure, and } \\
\text { biogenesis }\end{array}$ & 0 & 7 \\
\hline Transcription & 8 & 18 \\
\hline DNA replication, recombination, and repair & 2 & 4 \\
\hline Information storage and processing ${ }^{c}$ & 10 & 29 \\
\hline Intracell trafficking ${ }^{c}$ & 0 & 1 \\
\hline Energy production and conversion & 9 & 18 \\
\hline Amino acid transport and metabolism & 25 & 30 \\
\hline Nucleotide transport and metabolism & 7 & 2 \\
\hline Carbohydrate transport and metabolism & 20 & 16 \\
\hline Coenzyme metabolism & 0 & 2 \\
\hline Lipid metabolism & 1 & 7 \\
\hline $\begin{array}{l}\text { Secondary metabolites biosynthesis, } \\
\text { transport, and catabolism }\end{array}$ & 12 & 4 \\
\hline Metabolism $^{c}$ & 74 & 79 \\
\hline General function prediction only & 8 & 21 \\
\hline Function unknown & 8 & 24 \\
\hline Poorly characterized & 23 & 67 \\
\hline Unknownc & 39 & 112 \\
\hline Total & 147 & 245 \\
\hline
\end{tabular}

aThe differentially expressed genes were classified according to clusters of orthologous groups (COGs) as defined at http://www.ncbi.nlm.nih.gov/COG

${ }^{b}$ Number of genes activated or repressed (by having a ratio $\geq \pm 2.5$-fold) by ArcA.

'Bolded functional gene catagories contain a summary of the unbolded COG functional gene groups that are located in each of the previous lines. (i.e., >1), while genes activated by ArcA have negative values (i.e., $<1$ ).

\section{Microarray validation}

Normalized mRNA levels from qRT-PCR are shown in Table 2. The microarray and qRT-PCR data were $\log _{2}$ transformed and plotted (Figure 1). The correlation between the two sets of data was $0.87(\mathrm{p}<0.05)$.

\section{Logo graph and promoter analysis}

To determine whether a binding site for ArcA might be present in the region upstream of the candidate ArcAregulated genes, we searched the 5' regions of these highly affected genes (i.e., has a ratio $\geq \pm 2.5$-fold) for the presence of a putative ArcA-binding motif using a Salmonella logo graph (Figure 2) and found 155 genes contained potential ArcA binding sites. Furthermore, fifty-five out of the 147 ArcA-activated genes (37\%), and 100 out of the 245 ArcA-repressed genes (41\%) contained at least one putative ArcA-binding site (Additional file 1: Table S1).

\section{ArcA as a repressor}

Transcription of the genes required for aerobic metabolism, energy generation, amino acid transport, and fatty acid transport were anaerobically repressed by ArcA (Additional file 1: Table S1). In particular, the genes required for cytochrome-o-oxidase, succinyl-CoA synthetase, glutamate/aspartate transport, trehalose-6phosphate biosynthesis, long-chain fatty acids transport, spermidine/putrescine transport, dipeptide transport, the genes encoding the two-component tricarboxylic transport system and the site-specific DNA factor for inversion stimulation (fis) were among the highest repressed by ArcA. Genes required for L-lactate transport and metabolism, phosphate transport, acetyl-CoA transferase, APC family/D-alanine/D-serine/glycine transport, putative cationic amino acid transporter, peptide methionine sulfoxide reductase, multiple antibiotic resistance operon, as well as many poorly characterized genes were also repressed by ArcA (Additional file 1: Table S1).

Additionally, some genes related to Salmonella virulence were repressed by ArcA. For example, the expression of the $m g t C B$ operon (member of SPI-3) that is required for $\mathrm{Mg}^{2+}$ transport/growth in low-magnesium and involved in systemic infections in mice/intramacrophage survival [37-40], genes constituting the lambdoid prophage Gifsy-1 that contributes to the virulence of $S$. Typhimurium [41], and genes coding for a leucinerich repeat protein (sspH2) that is translocated by and coordinately regulated with the SPI-2 TTSS [42] were highly repressed by ArcA (Figure 3A and Additional file 1: Table S1). 


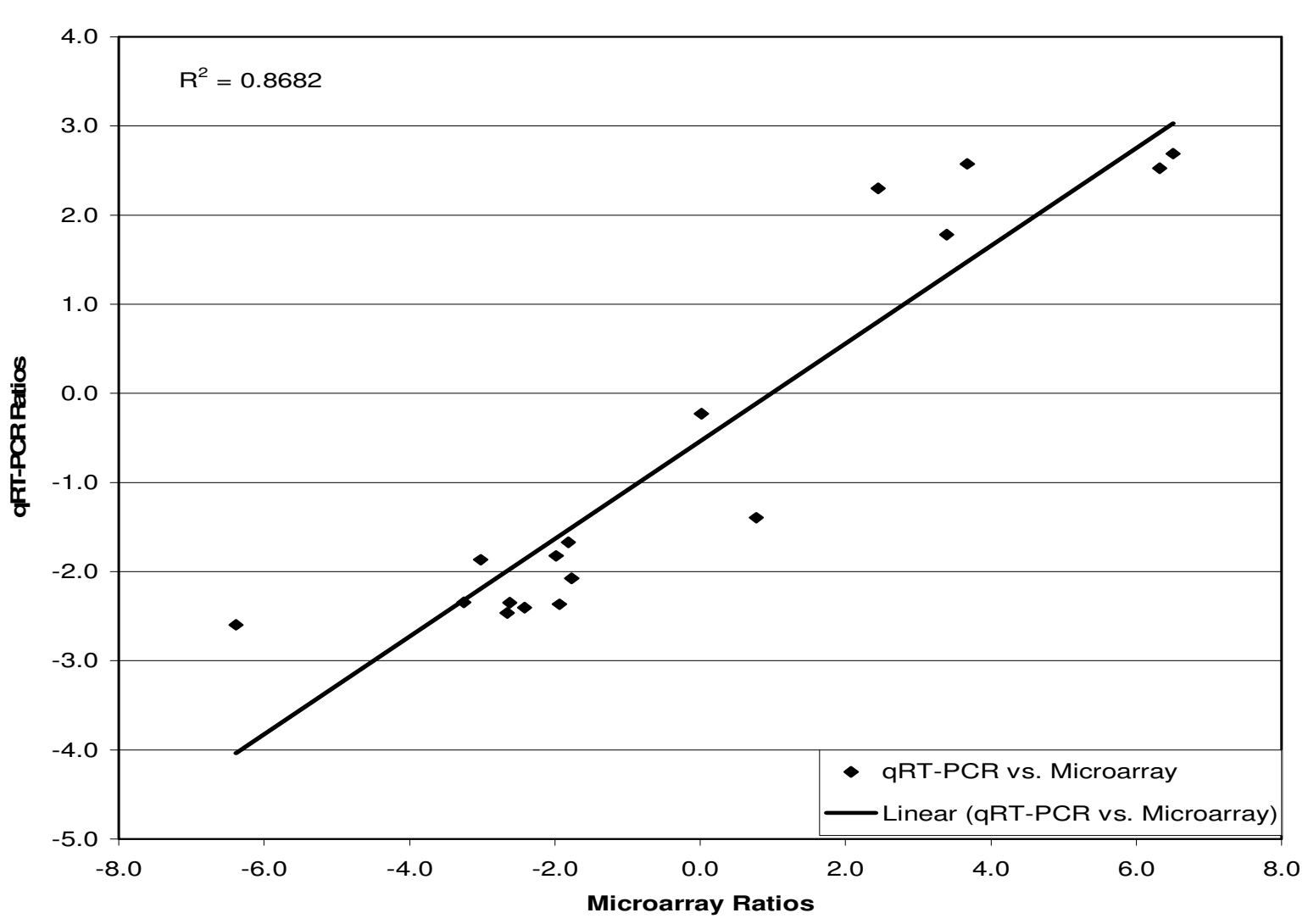

Figure 1 Correlation between the microarray and the qRT-PCR data of 17 randomly selected genes. The ratios of changes in gene expression, from the microarray (each S. Typhimurium ORF was spotted in triplicate on the slide) and qRT-PCR experiments, for the arcA mutant relative to the WT were $\log _{2}$ transformed and linearly correlated. The genes selected and the primers used in qRT-PCR are listed in Table 2. Three amplifications of each of the 17 genes were made using 1:5:25 dilutions of the total RNA.

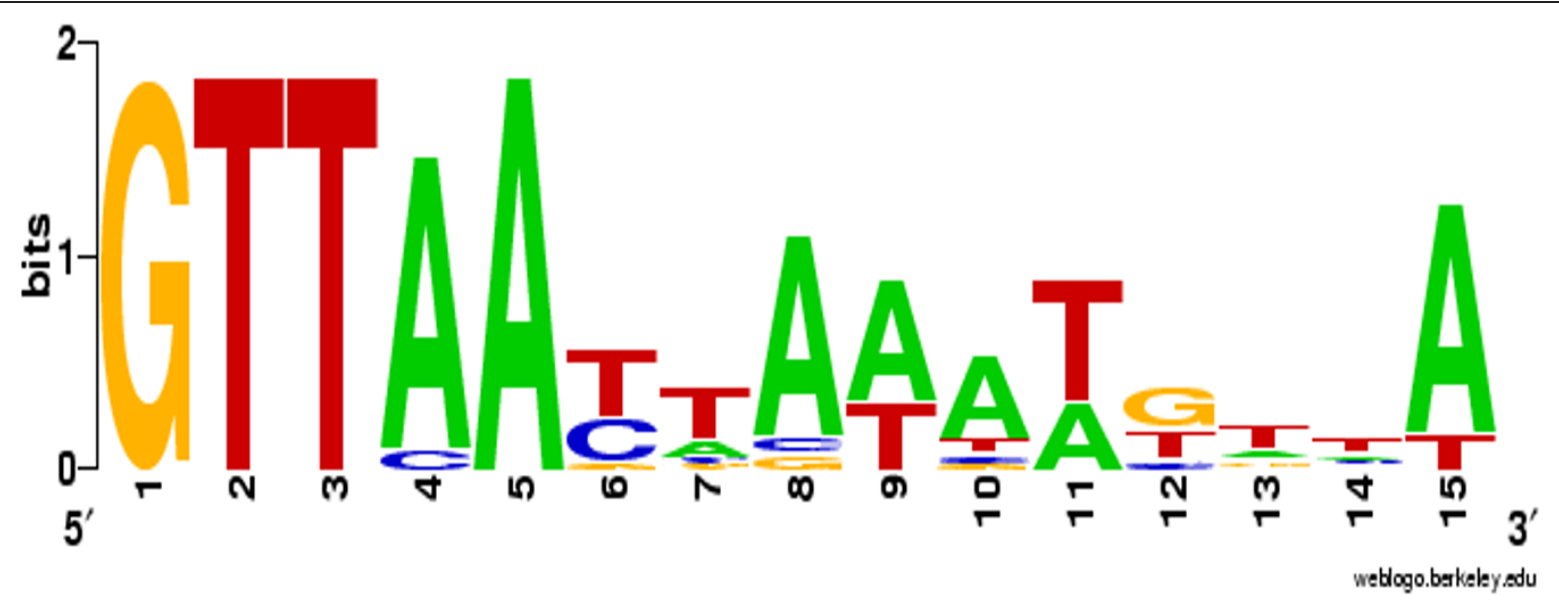

Figure $\mathbf{2}$ Logo of the information matrix obtained from the alignment of ArcA sequences for S. Typhimurium. Sequences were obtained by searching the S. Typhimurium LT2 genome [Accession \#: AE006468 (chromosome) and AE606471 (plasmid)] with known ArcA sequences derived from the corresponding ArcA-regulated genes in E. coli. A total of 20 E. coli sequences were used to obtain the logo shown. The total height of each column of characters represents the amount of information [measured in bits, which is the maximum entropy for the given sequence type (ex. $\log _{2} 4=2$ bits for DNA/RNA and $\log _{2} 20=4.3$ bits for proteins)] for that specific position and the height of each individual character represents the frequency of each nucleotide. 


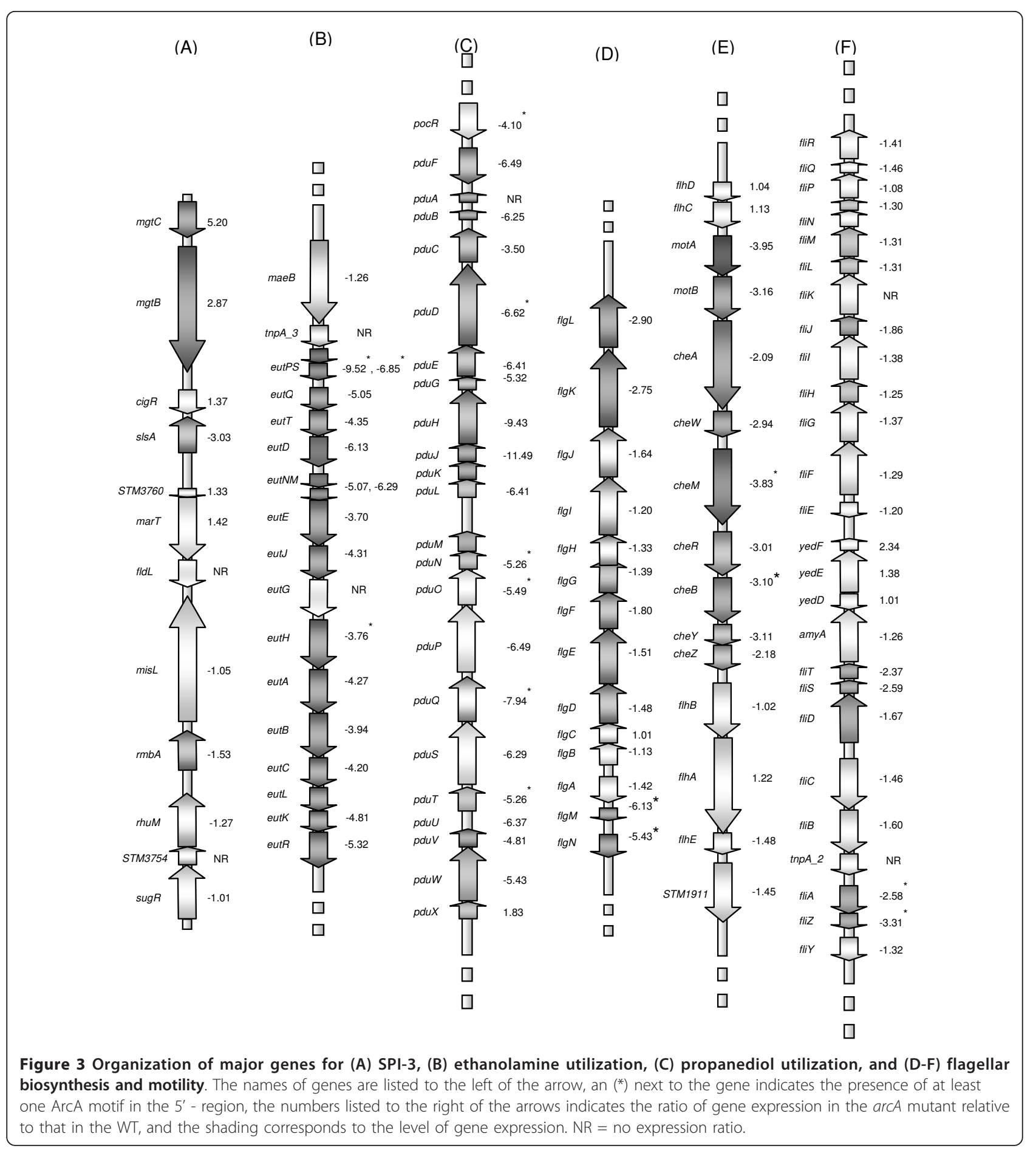

\section{ArcA as an activator}

Several of the genes involved in regulating flagellar biosynthesis, motility, chemotaxis, sugar transport, metabolism, and glycogen biosynthesis were found to be anaerobically activated by ArcA (Figure 3D-F and Additional file 1: Table S1). In particular, several of the middle (class 2) flagellar genes and late flagellar (class 3) genes had lower transcript levels in the $\operatorname{arcA}$ mutant than in the WT strain (Figure 3D-F). There was no significant difference in the transcript levels of the early flagellar genes (class 1) $f l h D$ and $f l h C$, whose gene products FlhD/ FlhC are the master regulators of flagellar biosynthesis (Figure 3E). Additionally, several newly identified flagellar genes [43] (i. e., $m c p A, m c p C$, and $c h e V$ ) had lower 
expression levels in the $\operatorname{arcA}$ mutant than in the WT (Additional file 1: Table S1), while the expression of $m c p B$ was not affected. Furthermore, genes coding for transcriptional repressor CytR, nitrite reductase, 2dexoyribose-5-phosphate aldolase, thymidine phosphorylase, lysine/cadaverine transport protein, putrescine/ ornithine antiporter, ornithine decarboxylase, ethanolamine operon, and propanediol operon as well as its transcriptional regulator PocR were activated by ArcA (Figure 3B and 3C, and Additional file 1: Table S1).

The expression of SPI-1 associated genes was not affected by a mutation in $\operatorname{arcA}$. However, two SPI-3 genes, $s l s A$, encoding a putative inner membrane protein required for colonization of chickens and calves [1,44], and STM3784, a putative sugar phosphotransferase, were activated by ArcA as their expression levels were significantly lower in the mutant than in the WT (Figure 3A and Additional file 1: Table S1).

\section{Phenotype of the $\operatorname{arc} A$ mutant}

Next, we correlated some of the microarray findings with the corresponding phenotypes of the WT and the $\operatorname{arcA}$ mutant strains.

\section{a. Flagellar biosynthesis and swarming motility}

The microarray data showed that, in anaerobiosis, the expression of the flagellar biosynthesis, motility, and chemotaxis genes was lower in the $\operatorname{arcA}$ mutant than in the WT. Therefore, we compared the swarming motility of the WT and the $\operatorname{arcA}$ mutant in soft agar under anaerobic conditions (Table 4). The data indicated that the $\operatorname{arc} A$ mutant was $\sim 100 \%$ non-motile compared to the WT and that the inclusion of parcA complemented $(\sim 57 \%)$ this phenotype. We also compared the WT and the $\operatorname{arc} A$ mutant under anaerobic conditions for the presence of flagella by using SEM (Figure 4A and 4C, left panel) and TEM (Figure 4B and 4D, right panel). The data (Table 4 and Figure 4) clearly showed that the $\operatorname{arc} A$ mutant Lacked flagella and was non-motile.

\section{b. Virulence in mice}

The microarray data (Additional file 1: Table S1) showed that ArcA does not significantly regulate the transcription of the virulence genes found in SPI-1, which are important for the ability of Salmonella to invade host epithelial cells [2,3,45-47]. However, few

Table 4 Effect of the arcA mutation on swarming motility under anaerobic conditions

\begin{tabular}{lcc}
\hline \multicolumn{2}{c}{ Diameter $(\mathbf{c m})$} \\
\hline Genotype & Anaerobic $^{\mathbf{a}}$ & \% $^{\mathbf{b}}$ \\
\hline WT & $8.0 \pm 0.1$ & 100 \\
\hline arcA mutant & $0.0 \pm 0.0$ & 0 \\
\hline Mutant/parcA & $4.6 \pm 0.1$ & 57 \\
\hline
\end{tabular}

${ }^{a}$ Average of three replicates.

${ }^{\mathrm{b}}$ Percent relative to the wild-type (WT). virulence genes related to SPI-2 (sspH2) and SPI-3 ( $m g t C B, s l s A$, STM3784) were affected by ArcA. Therefore, to evaluate these findings, we tested the virulence of the $\operatorname{arcA}$ mutant in a murine model of mucosal and acute infection using immunocompetent C57BL/6 mice. The $\operatorname{arc} A$ mutant was as virulent as the WT strain when $250 \mathrm{CFU} /$ mouse were inoculated via i.p. (Figure $5 \mathrm{~A})$. Since intramacrophage survival and replication of Salmonella permits the colonization of the spleen and liver of mice $[4,48]$, a further virulence comparison of the WT and the $\operatorname{arcA}$ mutant was performed using a mixed infection assay. The data showed that the $\operatorname{arcA}$ mutant had a moderate competitive survival advantage in the reticuloendothelial system compared to the WT in all systemic organs examined following a p.o. or i.p. mixed infection (Figure 5B). In the majority of the mice, the $\operatorname{arc} A$ mutant was isolated in higher numbers than the WT, although these increases were not statistically significant $(p>0.05)$. The data generated with the competitive assays is in agreement with i.p. infection data, where the mice succumbed with similar kinetics after infection with $\operatorname{arcA}$ or WT bacteria.

\section{Discussion}

Although there are several reports on the regulation of specific genes by ArcA in non-virulent strains of E. coli [6-9,13-17,49-56] and in Salmonella spp. [57]. This is the first genome-wide study on the regulatory role of ArcA in S. Typhimurium (14028s) under anaerobic conditions. ArcA was found to directly or indirectly control the expression of at least 392 genes. In particular, we showed that ArcA is involved in energy metabolism, flagella biosynthesis, and motility. Additionally, the $\operatorname{arc} A$ mutant was as virulent as the WT, although it was nonmotile. Furthermore, prior to the present report, none of the virulence genes (i. e., SPI-3 and Gifsy-1) had been identified as part of the Salmonella ArcA regulon. Finally, several genes involved in metabolism previously identified as being regulated by ArcA in E. coli [5-17,49-52] were also identified in the present study (Additional file 1: Table S1).

\section{Logo comparison}

In a recent study, a logo was used to graphically compare multiple ArcA sequence alignments of Shewanella oneidensis [58] to that of E. coli [12]. The analysis revealed subtle changes in base pairs at each position between the sequences. Although the ArcA binding motifs of $S$. oneidensis and E. coli were similar, the $\operatorname{arc} A$ regulons and the physiological function of ArcA in these two organisms were different [58]. When comparing the ArcA logos of E. coli and S. oneidensis to the one generated herein for $S$. Typhimurium, we found that there is similarity between $S$. Typhimurium and both $E$. coli and $S$. 


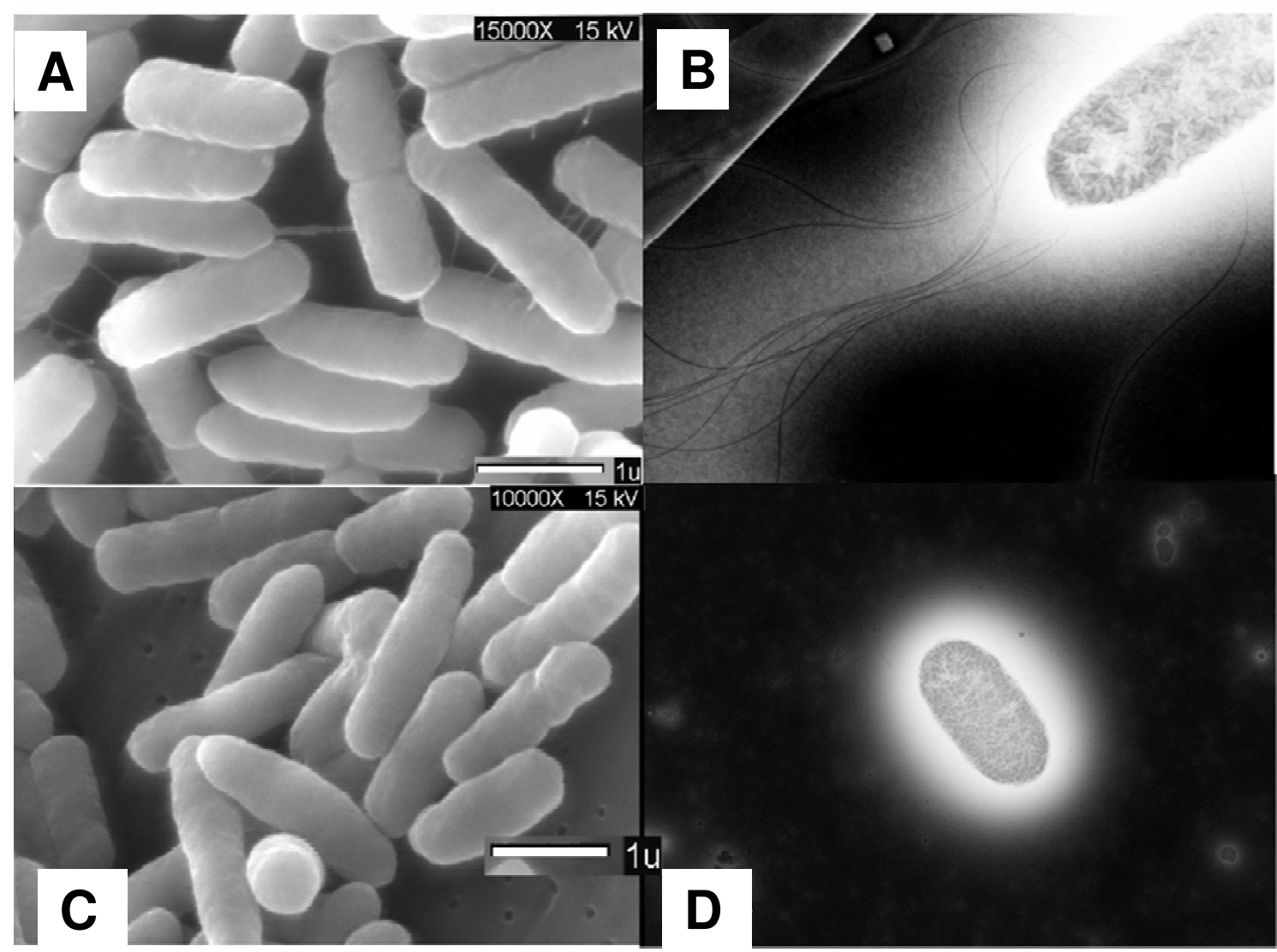

Figure 4 Comparison of the WT and the arcA mutant for surface appendages and flagella via microscopy. Scanning electron microscopy (SEM) was used to evaluate the WT (A) and the $\operatorname{arcA}$ mutant (C) for the presence/absence of surface appendages and negative staining followed by transmission electron microscopy (TEM) was used to evaluate the WT (B) and the arcA mutant (D) for the presence/absence of flagella. Cells were grown anaerobically in LB-MOPS-X media and the samples were prepared as described in Materials and Methods.

oneidensis. However, while there is very little variation between the nucleotide sequences at each base pair of $S$. Typhimurium and E. coli, there is much more variation between $S$. Typhimurium and S. oneidensis. Therefore, when comparing the genes regulated by ArcA in these three organisms, it is evident that the ArcA regulons of E. coli and S. Typhimurium are more similar than that of S. oneidensis.

\section{ArcA and carbon metabolism}

Comparing our microarray data in $S$. Typhimurium to the published data of $E$. coli $[5,12]$, there are several aspects pertaining to metabolic regulation that are similar between these two organisms. Anaerobically, several ArcA-repressed genes identified in our microarray data are involved in metabolism and transport, while ArcAactivated genes included those coding for enzymes involved in glycogen synthesis and catabolism as well as those for gluconeogenesis. Expression of many of these genes was consistent with those reported in $E$. coli
[5,9,11-14,52], H. influenzae [59], and S. oneidensis [60]. The genes of the two-component tricarboxylic transport system (tctE, STM2786, STM2787, STM2788, and STM2789) were the most highly repressed by ArcA (Additional file 1: Table S1). This was not surprising since transport systems for substrates of aerobic pathways have been suggested to be candidates for regulation by ArcA [14]. A similar pattern of anaerobic regulation of these enzymes has also been seen in our previous global analysis of Fnr [20] (Additional file 1: Table S2).

In $E$. coli, the CsrA (carbon storage regulator) protein acts post-transcriptionally to balance carbon flow in the cell by activating genes involved in glycolysis and repressing genes participating in gluconeogenesis [61]. In the present study, we found that the transcription of $\operatorname{csr} A$ was not affected by a mutation in $\operatorname{arc} A$, presumably CsrA remained fully functional in the mutant to provide the switch from glycolysis to gluconeogenesis by repressing the genes associated with glycolysis and activating 


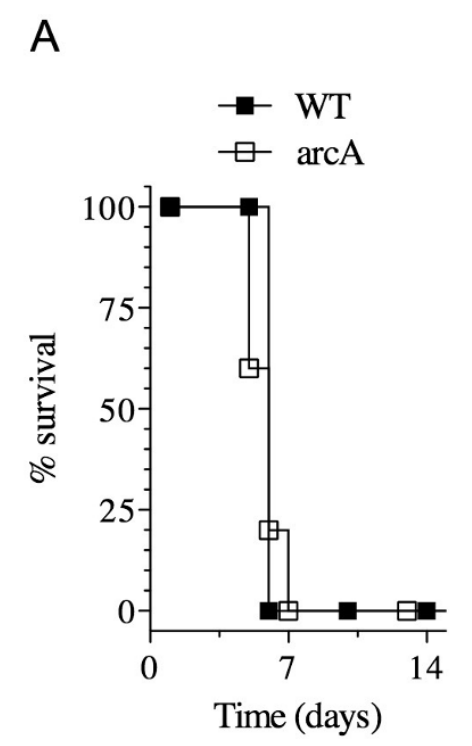

B
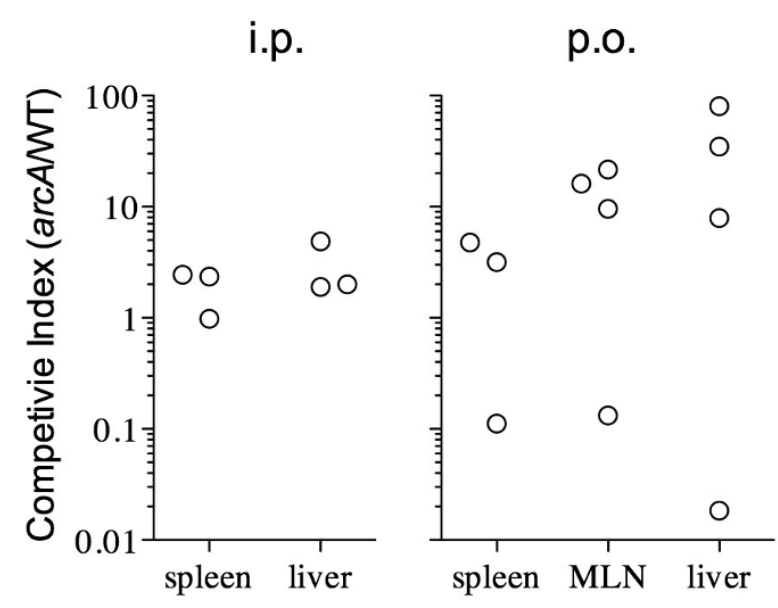

Figure 5 Virulence comparison of the WT and the arcA mutant in 6-8 week old C57BL/6 mice. (A) Single infection assays, where two groups of five mice per strain (WT and arcA mutant) were challenged intraperitoneally using 250 CFU/mouse, as described in Materials and Methods. Percent survival is the number of mice surviving relative to the number of mice challenged at zero time; (B) Competitive infection assays, where groups of three 6-week-old mice were infected orally (p. o.) or i. p. with a 1:1 mixture of S. Typhimurium $14028 \mathrm{~s}$ and its isogenic arcA mutant. After 4 or 6 days following i.p. or p.o. infection, respectively, mice were euthanized and mesenteric lymph nodes (MLN), liver, and spleen were collected for enumeration of the WT and the mutant. The competitive index (Cl) was calculated as described in the Materials and Methods.

those genes affiliated with gluconeogenesis. A mutation in $\operatorname{arcA}$ caused a 2.65 -fold increase in the expression of ptsG, a glucose-specific IIB component of the PTS-system (STM1203), which is required for the first step in glucose metabolism. A similar 2-fold increase was noticed in E. coli and the binding of ArcA to the promoter of pts $G$ was demonstrated [54]. Under anaerobic conditions and in the absence of electron acceptors, where the reduced quinone carriers can activate ArcA, it seems to be more advantageous for $S$. Typhimurium and E. coli cells to control the rate of glucose metabolism in order to reduce the rate of production of acidic end-products. Thus, the adaptation to anaerobic environments requires the regulation of the rate of glycolysis, the utilization of the fermentation products, and the use of the tricarboxylic acid cycle and the glyoxylate shunt in order for the organism to compete with others during sudden changes in oxygen concentrations.

E. coli contains two oxidases in its respiratory chain. The first, which is known to decrease under anaerobic growth conditions and has a low affinity for oxygen, cytochrome o (encoded by the cyoABCDE) and the second, which is known to increase during anaerobic growth and has a high affinity for oxygen, cytochrome $d$ (encoded by the cydAB) [62]. Our data show that, anaerobically, ArcA repressed the cyo operon (Additional file 1: Table S1), while the expression of $c y d$ operon was slightly reduced in the $\operatorname{arcA}$ mutant relative to WT (i.e., ArcA is required for the activation of $c y d$ ). These results are in agreement with previous reports showing that a mutation in either $\operatorname{arc} A$ or $\operatorname{arc} B$ diminished $c y d$ operon expression under aerobic and anaerobic conditions, while either mutation did not fully abolish repression of the cyo operon anaerobically [55].

Our data showed that the $\operatorname{arcA}$ mutant has a longer doubling time compared to the WT under anaerobiosis. This result is supported by our microarray data whereby several genes responsible for glycogen synthesis and catabolism as well as those for gluconeogenesis were down-regulated in the $\operatorname{arc} A$ mutant compared to the WT, while those genes regulating the tricarboxylic acid cycle (TCA), glyoxylate shunt, glycolysis, pentose phosphate shunt, and acetate metabolism were all upregulated in the $\operatorname{arcA}$ mutant compared to the WT. Thus, under anaerobiosis, in $\operatorname{arc} A$ mutant cells, an energy imbalance is created, whereby the cells direct products through various metabolic pathways typically used during aerobiosis due to the de-repression of the TCA cycle, which subsequently yields a pool of reducing equivalents that can only be reduced in the presence of electron acceptors. Normally, during anaerobiosis, less energy in the form of ATP is generated. Thus, the $\operatorname{arcA}$ mutant cells appear to waste a vast amount of energy to express and maintain metabolic pathways that are not required under anaerobiosis, which may contribute to the slower growth rate of the culture. However, further work is required to determine NAD/NADH pools in the $\operatorname{arcA}$ mutant compared to the WT. 


\section{ArcA and hydrogenases}

Hydrogen gas $\left(\mathrm{H}_{2}\right)$ is an important energy source for the survival of pathogens in vivo [63] and is produced in the host via colonic bacterial fermentations [64]. Our results indicated that the $h y b$ operon was activated in the $\operatorname{arcA}$ mutant, but these levels were not within our \pm 2.5 -fold threshold. Additionally, STM1538, STM1539, STM1786, STM1788, STM1790, and STM1791, which also code for hydrogenases were significantly repressed in the $\operatorname{arc} A$ mutant (Additional file 1: Table S1), in agreement with previous results [65].

ArcA regulation of cobalamine synthesis and metabolism Propanediol (encoded by the $p d u$ operon), a fermentation product of rhamnose or fucose [66,67], and ethanolamine (encoded by the eut operon), an essential component of bacterial and eukaryotic cells, can be used by Salmonella as carbon and energy sources in the mammalian gastrointestinal tract [67]. Vitamin $B_{12}$, its synthesis being encoded by the $c o b$ operon, is required for the metabolism of ethanolamine and propanediol, while anaerobic utilization of these substrates also requires the use of tetrathionate $(t t r)$ as a terminal electron acceptor [68]. The positive regulatory protein, PocR, is necessary for the induction of the $c o b$ and $p d u$ operons and is subject to global regulatory control via ArcA and/or Crp [69,70].

In vivo expression technology (IVET) has shown that genes coding for cobalamine synthesis and 1,2-propanediol degradation are required for Salmonella replication in macrophages [71], that $p d u$ genes may be necessary for intracellular proliferation within the host [72], and that $p d u$ mutations, but not $c o b$ mutations can be attributed to a defect in virulence [73,74]. Strains harboring mutations in ethanolamine utilization genes are attenuated in macrophages and in BALB/c mice when delivered orally, but not intraperitoneally [75].

Our data (Additional file 1: Table S1) show that pocR, the transcriptional regulator of propanediol utilization, was significantly activated by ArcA. Furthermore, all of the genes in the eut and $p d u$ operons were activated by ArcA (Figure 3 and Additional file 1: Table S1). An $\operatorname{arcA}$ mutation in $S$. Typhimurium has been shown to cause reduced expression of the $c o b$ and $p d u$ operons during anaerobic growth [69]. Interestingly, when comparing the data from the present study and our Fnr data [20], we found that ArcA and Fnr share in the regulation of the eut operon (Additional file 1: Table S2), while the $p d u$ operon was more positively regulated by ArcA than by Fnr. Transcription of tetrathionate (ttr operon) was activated at equal levels by both Fnr and ArcA. Previous studies $[68,70]$ have shown that induction of the ttr operon is affected by Fnr, but not by ArcA. This may suggest that Fnr plays a more significant role in regulating the eut operon [70], while ArcA acts more significantly on regulating the genes associated with the $p d u$ operon. Although, both the $c o b$ and $p d u$ operons were both activated in the $\operatorname{arc} A$ mutant, this may be due to the effects of $\operatorname{arc} A$ on anaerobic pocR expression, which subsequently regulates the rest of each of these operons.

\section{ArcA and flagellar biosynthesis/swarming motility/ chemotaxis}

Our data show that, anaerobically, ArcA positively regulates the expression of genes involved in flagellar biosynthesis, swarming motility, and chemotaxis (Figures 3 and 4; Table 3 and Additional file 1: Table S1) including many newly identified flagellar genes (i.e., $m c p A C$ and cheV) [43]. Previously, we found that Fnr positively regulates many of the same the flagellar and chemotaxis genes under anaerobic conditions [20]; indeed the anaerobic motility phenotype of the $\operatorname{arc} A$ mutant was indistinguishable from that previously seen with the $f n r$ mutant [20]. Furthermore, the expression of the flagellar biosynthesis, motility, and chemotaxis genes under anaerobiosis was more highly activated by Fnr than by ArcA (Additional file 1: Table S2).

A plethora of regulators affect the expression of $f l h D C$ and motility in E. coli and S. Typhimurium [20,76-86]. Our data showed that ArcA activates class 2 and class 3 flagellar genes and we identified a potential ArcA binding site in filA, filZ, flgM, and flgN. ArcA seems to slightly repress $f l h D C$ (i. e., below our cut-off level of \pm 2.5 -fold). In agreement with our work, ArcA was recently shown to be necessary for the expression of fliA in E. coli, but not for the master regulator, flhDC [56]. However, using in silico analysis, the authors did not identify ArcA binding sites in the promoter regions of fliA or other class 2 flagellar genes [56],

\section{ArcA and antioxidant defenses}

Under aerobic conditions, ArcA has been reported to be essential for the resistance of $S$. Enteritidis to RNS and ROS via an unknown mechanism [57]. In agreement with this report [57], we found that the $\operatorname{arcA}$ mutant of $S$. Typhimurium to be more sensitive to hydrogen peroxide $\left(\mathrm{H}_{2} \mathrm{O}_{2}\right)$ under aerobic conditions (Additional file 1: Figure S2). Anaerobically, our data indicate that the expression of many of the antioxidant genes [i.e.: $\operatorname{sod} A$, $\operatorname{sodB}$, $\operatorname{sod} C 1$, and $\operatorname{sod} C 2$ (coding for superoxide dismutases) and kat $G$ and katE (coding for hydroperoxidases), and $h m p A$ (coding for flavohemoglobin)] were not significantly affected by ArcA; however the expression of STM1731 (Mn-catalase, katN) was significantly increased in the $\operatorname{arcA}$ mutant compared to the WT (Additional file 1: Table S1). To date, the physiological role of Mn-catalase (KatN) in $S$. Typhimurium has not been thoroughly examined, although, its ability to 
scavenge $\mathrm{H}_{2} \mathrm{O}_{2}$ and work together with $\mathrm{KatE}$, KatG, and the hydroperoxide reductases to protect the cell from oxidative stress has been demonstrated [87]. In addition, it has been proposed that the substitution of iron by manganese as a co-factor might be a way to circumvent iron restriction by the host during infection [88].

\section{ArcA and pathogenesis}

The majority of the virulence factors ( 200 genes) of $S$. Typhimurium are chromosomally located within Salmonella pathogenicity islands (SPIs) [2,89-93]. SPI-1 and SPI-2 both encode TTS̄Ss $[4,45,94]$. SPI-1 effectors' proteins are required for epithelial cell invasion [95], while SPI-2 encodes secreted proteins, their specific chaperones [4], and a two-component regulatory system $[96,97]$, are all required for intracellular replication. Recently, SPI-1 invasion genes were found to be required for intramacrophage survival [98] and systemic infection in mice [99]. Our data have shown that most of the SPI-1 through SPI-5 genes were not significantly regulated by ArcA, with the exception of three genes contained within SPI-3 including, $m g t C, m g t B$, and $s l s A$ (Figure 3 and Additional file 1: Table S1). Thus, it is not surprising that our $\operatorname{arcA}$ mutant was determined to be as virulent as the WT strain following individual infection studies (Figure $5 \mathrm{~A}$ ), but was slightly more persistent than the WT following o. p. and i. p. competitive infection studies (Figure 5B), however, the difference was not statistically significant ( $\mathrm{p}>0.05)$.

Flagellar regulons have been shown to influence virulence gene expression in several pathogenic microorganisms [100-106]. Interestingly, data from our previous study [20], showed that the fnr mutant was non-motile and non-virulent, while in the present study, the $\operatorname{arc} A$ mutant was non-motile, but remained virulent. Clearly, the lack of motility does not necessarily correlate with the lack of virulence in $S$. Typhimurium.

\section{Overlapping global regulation by $\operatorname{ArcA}$ and $\mathrm{Fnr}$}

ArcA and Fnr are two well known redox regulators in E. coli, S. Typhimurium, and other bacteria. We previously published the first report on the global role of Fnr in anaerobically grown $S$. Typhmurium [20]. The present study is the first report on the global regulatory role of ArcA in the same organism under the same experimental conditions and statistical constraints. Therefore, it is possible and reliable to compare genes/ operons regulated by these two important transcriptional factors (i. e., ArcA and Fnr). The data indicated that ArcA and Fnr shared in the regulation of 120 genes; while the numbers of genes solely regulated by either ArcA or Fnr were 272 and 191, respectively. The 120 genes that were regulated by either ArcA or Fnr are listed (Additional file 1: Table S2). These include genes involved in cytochrome c oxidase (cyoABCDE), glutamate/aspartate transport ( $g l t l J K L)$, dipeptide transport $(d p p A B C D F)$, succinyl-CoA synthetase $-\alpha \& \beta$ subunits (sucDC), tricarboxylic transport (STM2786, STM2787, STM2788), L-lactate transport and metabolism (lldPRD), nitrite reductase ( $n r f A B), 2$-dexoyribose-5-phosphate aldolase $(\operatorname{deo} C)$, thymidine phosphorylase $(\operatorname{deo} A)$, aerotaxis sensor receptor (aer), ethanolamine utilization (eut operon - STM2454-2470), and several genes involving flagellar biosynthesis, motility, and chemotaxis. Interestingly, most of the 120 genes were regulated by ArcA and Fnr in the same fashion (i.e., repressed or activated) except for yneB (putative fructose-1,6-bisphosphate aldolase - STM4078), which was activated by ArcA, but repressed by Fnr (Additional file 1: Table S2). The opposing regulation of yneB by ArcA and Fnr indeed warrant further studies.

\section{Conclusion(s)}

Herein, we report on the role of the two-component regulator, ArcA, in the genome-wide response to oxygen in Salmonella. Our data clearly demonstrate that ArcA serves, directly or indirectly, as a regulator/modulator of genes involved in aerobic/anaerobic energy metabolism and motility. In a recent study [20], we demonstrated that the oxygen sensing, global regulator, Fnr participates in coordinating anaerobic metabolism, flagellar biosynthesis, motility, chemotaxis, and virulence in $S$. Typhimurium. In the present study, we identified a set of 120 genes whose regulation is shared between ArcA and Fnr. We also demonstrated that Fnr plays a more hierarchical role than ArcA in pathogenesis. Furthermore, under our experimental conditions, we demonstrated that the lack of motility does not necessarily correspond to the lack of virulence in $S$. Typhimurium.

\section{Additional material}

Additional file 1: Analysis of the ArcA regulon in anaerobically grown Salmonella enterica sv. Typhimurium. Identification of ArcA by Western blot; Effects of $\mathrm{H}_{2} \mathrm{O}_{2}$ on viability of the ArcA mutant; List of genes differentially regulated by ArcA; and List of genes shared with the Fnr regulon. A. Supplemental Methods: Western blot analysis of ArcA. $\mathrm{H}_{2} \mathrm{O}_{2}$ survival assays. B. Supplemental Figures: Figure S1. Western blot of total proteins of the WT, arcA mutant, and $\operatorname{arc} \overline{A^{-} / p \operatorname{parcA}}$ complement strains. Figure S2. Effects of hydrogen peroxide on viability of the WT and the $\operatorname{arc} A$ mutant under anerobiosis. C. Supplemental Tables: Table S1. Differentially expressed genes and the presence/absence of putative ArcA-binding motifs in their $5^{\prime}$ regions. Table S2. Comparison of the 120 genes shared between the ArCA and the Fnr regulons of S. Typhimurium under anaerobiosis.

\section{Acknowledgements}

This work was supported in part by the North Carolina Agricultural Research Services (to HMH), and by NIH grants R01Al034829, R01AI022933,

R21Al057733, and R01Al52237 and generous gifts from Mr. Sidney Kimmel 
and Mr. Ira Lechner (MM and SP), NIH grants Al054959 and RR16082 (AV-T and JJ-C). We appreciate the donation of the anti-ArcA antibodies from Dr. Philip Silverman and Ms. Robin Harris at the Department of Botany and Microbiology, University of Oklahoma. We would also like to thank Valerie Knowlton for her assistance with the microscopy. We are grateful to Drs. Gabriele Gusmini and Russell Wolfinger for their assistance with the statistical analyses/SAS software.

\section{Author details}

'Department of Microbiology, North Carolina State University, Raleigh, North Carolina 27695-7615 USA. ${ }^{2}$ Department of Microbiology, University of Colorado School of Medicine, Denver, Colorado 80262 USA. ${ }^{3}$ The Vaccine Research Institute of San Diego, 10835 Road to the Cure, Suite 105, San Diego, California 92121 USA. ${ }^{4}$ Pfizer, Inc., 4300 Oak Park Road, Sanford, NC 27330-9550 USA. ${ }^{5}$ Department of Food Science and Nutrition, University of Minnesota, St. Paul, MN 55108-1038 USA.

\section{Authors' contributions}

MRE transduced and confirmed the arcA mutant, constructed and confirmed the complement plasmid (parcA), performed the Western blotting, performed the growth studies in aerobic and anaerobic conditions, compared our microarray data to that in other studies, conducted the GRTPCR and lethality studies in the presence of hydrogen peroxide, participated in the motility studies, and contributed to the writing/editing of the manuscript. RCF conducted the microarrays and performed the analysis, constructed the logo, participated in motility studies, and contributed to the editing of the manuscript. AV-T and JJ-C carried-out all of the mice studies. MM and SP constructed and provided the microarray slides. $\mathrm{HMH}$ conceived the idea, directed the research, and contributed to the writing/editing of the manuscript. All authors have read and approved the final manuscript.

Received: 1 November 2010 Accepted: 21 March 2011

Published: 21 March 2011

\section{References}

1. Morgan E, Campbell JD, Rowe SC, Bispham J, Stevens MP, Bowen AJ, et al Identification of host-specific colonization factors of Salmonella enterica serovar Typhimurium. Mol Microbiol 2004, 54:994-1010.

2. Galan JE: Salmonella interactions with host cells: type III secretion at work. Annu Rev Cell Dev Biol 2001, 17:53-86.

3. Wallis TS, Galyov EE: Molecular basis of Salmonella induced enteritis. Mol Microbiol 2000, 36:997-1005.

4. Cirillo DM, Valdivia RH, Monack DM, Falkow S: Macrophage-dependent induction of the Salmonella pathogenicity island 2 type III secretion system and its role in intracellular survival. Mol Microbiol 1998, 30:175-188.

5. Salmon KA, Hung SP, Steffen NR, Krupp R, Baldi P, Hatfield GW, et al: Global gene expression profiling in Escherichia coli K12: effects of oxygen availability and ArCA. J Biol Chem 2005, 280:15084-15096.

6. Chao GL, Shen J, Tseng CP, Park SJ, Gunsalus RP: Aerobic regulation of isocitrate dehydrogenase gene (icd) expression in Escherichia coli by the arcA and fnr gene products. J Bacteriol 1997, 179:4299-4304.

7. Park S-J, Chao G, Gunsalus RP: Aerobic regulation of the sucABCD genes of Escherichia coli, which encode alpha-ketoglutarate dehydrogenase and succinyl coenzyme A synthetase: roles of ArcA, Fnr, and the upstream sdhCDAB promoter. J Bacteriol 1997, 179:4138-4142.

8. Gunsalus RP, Park S-J: Aerobic-anaerobic regulation in Escherichia coli: control by the ArcAB and Fnr regulons. Res Microbiol 1994, 145:437-450.

9. Nystrom T, Larsson C, Gustafsson L: Bacterial defense against aging: role of the Escherichia coli ArcA regulator in gene expression, readjusted energy flux and survival during stasis. EMBO J 1996, 15:3219-3228.

10. Nunn WD: A molecular view of fatty-acid catabolism in Escherichia coli. Microbiol Rev 1986, 50:179-192.

11. Lin ECC, luchi S: Regulation of gene expression in fermentative and respiratory systems in Escherichia coli and related bacteria. Annu Rev Genet 1991, 25:361-387.

12. Liu XQ, De Wulf P: Probing the ArcA-P modulon of Escherichia coli by whole genome transcriptional analysis and sequence recognition profiling. J Biol Chem 2004, 279:12588-12597.

13. Shalel-Levanon S, San KY, Bennett GN: Effect of ArcA and FNR on the expression of genes related to the oxygen regulation and glycolysis pathway in Escherichia coli under growth conditions. Biotechnol Bioeng 2005, 92:147-159.

14. Iuchi S, Lin EC: arcA (dye), a global regulatory gene in Escherichia coli mediating repression of enzymes in aerobic pathways. Proc Natl Acad Sci USA 1988, 85:1888-1892.

15. luchi S, Chepuri V, Fu HA, Gennis RB, Lin ECC: Requirement for terminal cytochromes in generation of the aerobic signal for the arc regulatory system in Escherichia coli: study utilizing deletions and lac fusions of cyo and cyd. J Bacteriol 1990, 172:6020-6025.

16. Iuchi S, Aristarkhov A, Dong JM, Taylor JS, Lin ECC: Effects of nitrate respiration on expression of the Arc-controlled operons encoding succinate dehydrogenase and flavin-linked L-lactate dehydrogenase. J Bacteriol 1994, 176:1695-1701.

17. Cho BK, Knight EM, Palsson BO: Transcriptional regulation of the fad regulon genes of Escherichia coli by ArcA. Microbiology SGM 2006, 152:2207-2219.

18. Oshima T, Aiba H, Masuda Y, Kanaya S, Sugiura M, Wanner BL, et al: Transcriptome analysis of all two-component regulatory system mutants of Escherichia coli K-12. Mol Microbiol 2002, 46:281-291.

19. McClelland M, Florea L, Sanderson K, Clifton SW, Parkhill J, Churcher C, et al: Comparison of the Escherichia coli $\mathrm{K}-12$ genome with sampled genomes of a Klebsiella pneumoniae and three Salmonella enterica serovars, Typhimurium, Typhi and Paratyphi. Nucleic Acids Res 2000, 28:4974-4986.

20. Fink RC, Evans MR, Porwollik S, Vazquez-Torres A, Jones-Carson J, Troxell B, et al: FNR is a global regulator of virulence and anaerobic metabolism in Salmonella enterica serovar Typhimurium (ATCC 14028s). J Bacteriol 2007, 189:2262-2273.

21. Archer $C D$, Elliott $T$ : Transcriptional control of the nuo operon which encodes the energy-conserving NADH dehydrogenase of Salmonella typhimurium. J Bacteriol 1995, 177:2335-2342.

22. luchi S, Matsuda Z, Fujiwara T, Lin EC: The arcB gene of Escherichia coli encodes a sensor-regulator protein for anaerobic repression of the arc modulon. Mol Microbiol 1990, 4:715-727.

23. Sambrook J, Russell DW: Molecular Cloning: A Laboratory Manual Cold Spring Harbor, NY: Cold Spring Harbor Laboratory; 2001.

24. Porwollik S, Wong RMY, Sims SH, Schaaper RM, DeMarini DM, McClelland M: The delta uvrB mutations in the Ames strains of Salmonella span 15 to 119 genes. Mutat Res 2001, 483:1-11.

25. Satterthwaite FE: An approximate distribution of estimates of variance components. Biometrics Bull 1946, 2:110-114.

26. Higuchi $R$, Fockler $C$, Dollinger $G$, Watson R: Kinetic $P C R$ analysis: real-time monitoring of DNA amplification reactions. Biotechnology (NY) 1993, 11:1026-1030.

27. Miron M, Woody OZ, Marcil A, Murie C, Sladek R, Nadon R: A methodology for global validation of microarray experiments. Bmc Bioinformatics 2006, 7:333.

28. Robison K, McGuire AM, Church GM: A comprehensive library of DNAbinding site matrices for 55 proteins applied to the complete Escherichia coli K-12 genome. J Mol Biol 1998, 284:241-254.

29. Lee HS, Lee YS, Kim HS, Choi JY, Hassan HM, Chung MH: Mechanism of regulation of 8-hydroxyguanine endonuclease by oxidative stress: roles of fnr, arcA, and fur. Free Radic Biol Med 1998, 24:1193-1201.

30. Hassan HM, Schrum LW: Roles of manganese and iron in the regulation of the biosynthesis of manganese superoxide dismutase in Escherichia coli. FEMS Microbiol Rev 1994, 14:315-323.

31. van Helden J: Regulatory sequence analysis tools. Nucleic Acids Res 2003, 31:3593-3596.

32. Crooks GE, Hon G, Chandonia JM, Brenner SE: WebLogo: a sequence logo generator. Genome Res 2004, 14:1188-1190.

33. Allen CA, Fedorka-Cray PJ, Vazquez-Torres A, Suyemoto M, Altier C, Reeni Ryder $L$, et al: In vitro and in vivo assessment of Salmonella enterica serovar Typhimurium DT104 virulence. Infect Immun 2001, 69:4673-4677.

34. Wheeler DL, Barrett T, Benson DA, Bryant SH, Canese K, Church DM, et al: Database resources of the National Center for Biotechnology Information. Nucleic Acids Res 2005, 33:D39-D45.

35. Tatusov RL, Koonin EV, Lipman DJ: A genomic perspective on protein families. Science 1997, 278:631-637.

36. Tatusov RL, Fedorova ND, Jackson JD, Jacobs AR, Kiryutin B, Koonin EV, et al: The COG database: an updated version includes eukaryotes. BmC Bioinformatics 2003, 4:41. 
37. Snavely MD, Miller CG, Maguire ME: The $m g t B \mathrm{Mg}^{2+}$ transport locus of Salmonella typhimurium encodes a P-type ATPase. J Biol Chem 1991 266:815-823.

38. Groisman EA: The ins and outs of virulence gene expression: $\mathrm{Mg}^{2+}$ as a regulatory signal. Bioessays 1998, 20:96-101.

39. Blanc-Potard AB, Groisman EA: The Salmonella selC locus contains a pathogenicity island mediating intramacrophage survival. EMBO J 1997, 16:5376-5385.

40. Adkins JN, Mottaz HM, Norbeck AD, Gustin JK, Rue J, Clauss TRW, et al: Analysis of the Salmonella typhimurium proteome through environmental response toward infectious conditions. Mol Cell Proteomics 2006, 5:1450-1461.

41. Figueroa-Bossi N, Bossi L: Inducible prophages contribute to Salmonella virulence in mice. Mol Microbiol 1999, 33:167-176.

42. Miao EA, Scherer CA, Tsolis RM, Kingsley RA, Adams LG, Baumler AJ, et al: Salmonella typhimurium leucine-rich repeat proteins are targeted to the SPI1 and SPI2 type III secretion systems. Mol Microbiol 1999, 34:850-864.

43. Frye J, Karlinsey JE, Felise HR, Marzolf B, Dowidar N, McClelland M, et al: Identification of new flagellar genes of Salmonella enterica serovar Typhimurium. J Bacteriol 2006, 188:2233-2243.

44. Blanc-Potard AB, Solomon F, Kayser J, Groisman EA: The SPI-3 pathogenicity island of Salmonella enterica. J Bacteriol 1999, 181:998-1004.

45. Collazo CM, Galan JE: The invasion-associated type-III protein secretion system in Salmonella: a review. Gene 1997, 192:51-59.

46. Zhou D, Galan J: Salmonella entry into host cells: the work in concert of type III secreted effector proteins. Microbes Infect 2001, 3:1293-1298.

47. Zhang SP, Kingsley RA, Santos RL, Andrews-Polymenis H, Raffatellu M, Figueiredo J, et al: Molecular pathogenesis of Salmonella enterica serotype typhimurium-induced diarrhea. Infect Immun 2003, 71:1-12.

48. Shea JE, Beuzon CR, Gleeson C, Mundy R, Holden DW: Influence of the Salmonella typhimurium pathogenicity island 2 type III secretion system on bacterial growth in the mouse. Infect Immun 1999, 67:213-219.

49. Silverman PM, Rother S, Gaudin H: Arc and Sfr functions of the Escherichia coli K-12 arcA gene product are genetically and physiologically separable. J Bacteriol 1991, 173:5648-5652.

50. Silverman PM, Wickersham E, Rainwater S, Harris R: Regulation of the Fplasmid tray promoter in Escherichia coli $\mathrm{K}-12$ as a function of sequence context. J Mol Biol 1991, 220:271-279.

51. Six S, Andrews SC, Unden G, Guest JR: Escherichia coli possesses two homologous anaerobic C4-dicarboxylate membrane transporters (DcuA and DcuB) distinct from the aerobic dicarboxylate transport-system (Dct). J Bacteriol 1994, 176:6470-6478.

52. Cunningham L, Gruer MJ, Guest JR: Transcriptional regulation of the aconitase genes (acnA and acnB) of Escherichia coli. Microbiology UK 1997, 143:3795-3805.

53. Levanon SS, San KY, Bennett GN: Effect of oxygen on the Escherichia coli ArcA and FNR regulation systems and metabolic responses. Biotechnol Bioeng 2005, 89:556-564.

54. Jeong JY, Kim YJ, Cho N, Shin D, Nam TW, Ryu S, et al: Expression of ptsG encoding the major glucose transporter is regulated by ArcA in Escherichia coli. J Biol Chem 2004, 279:38513-38518.

55. Cotter PA, Gunsalus RP: Contribution of the Fnr and ArcA gene-products in coordinate regulation of cytochrome-o and cytochrome-d oxidase (cyoABCDE and cydAB) genes in Escherichia coli. FEMS Microbiol Lett 1992 91:31-36.

56. Kato $Y$, Sugiura M, Mizuno $T$, Aiba $H$ : Effect of the $\operatorname{arcA}$ mutation on the expression of flagella genes in Escherichia coli. Biosci Biotechnol Biochem 2007, 71:77-83.

57. Lu S, Killoran PB, Fang FC, Riley LW: The global regulator ArcA controls resistance to reactive nitrogen and oxygen intermediates in Salmonella enterica serovar Enteritidis. Infect Immun 2002, 70:451-461.

58. Gao H, Wang X, Yang ZK, Palzkill T, Zhou J: Probing regulon of ArcA in Shewanella oneidensis MR-1 by integrated genomic analysis. BMC Genomics 2008, 9:42.

59. Wong SMS, Alugupalli KR, Ram S, Akerley BJ: The ArcA regulon and oxidative stress resistance in Haemophilus influenzae. Mol Microbiol 2007 64:1375-1390

60. Gralnick JA, Brown CT, Newman DK: Anaerobic regulation by an atypical Arc system in Shewanella oneidensis. Mol Microbiol 2005, 56:1347-1357.

61. Romeo T: Global regulation by the small RNA-binding protein CsrA and the non-coding RNA molecule CsrB. Mol Microbiol 1998, 29:1321-1330.
62. Cotter PA, Chepuri V, Gennis RB, Gunsalus RP: Cytochrome o (cyoABCDE) and $d(c y d A B)$ oxidase gene expression in Escherichia coli is regulated by oxygen, $\mathrm{pH}$, and the fnr gene product. I Bacteriol 1990, 172:6333-6338.

63. Olson JW, Maier RJ: Molecular hydrogen as an energy source for Helicobacter pylori. Science 2002, 298:1788-1790.

64. Maier RJ: Availability and use of molecular hydrogen as an energy substrate for Helicobacter species. Microbes Infect 2003, 5:1159-1163.

65. Zbell AL, Benoit SL, Maier RJ: Differential expression of Nife uptake-type hydrogenase genes in Salmonella enterica serovar Typhimurium. Microbiology 2007, 153:3508-3516.

66. Obradors N, Badia J, Baldoma L, Aguilar J: Anaerobic metabolism of the Lrhamnose fermentation product 1,2-propanediol in Salmonella typhimurium. J Bacteriol 1988, 170:2159-2162.

67. Badia J, Ros J, Aguilar J: Fermentation mechanism of fucose and rhamnose in Salmonella typhimurium and Klebsiella pneumoniae. Bacteriol 1985, 161:435-437.

68. Price-Carter M, Tingey J, Bobik TA, Roth JR: The alternative electron acceptor tetrathionate supports B-12-dependent anaerobic growth of Salmonella enterica serovar Typhimurium on ethanolamine or 1,2propanediol. J Bacteriol 2001, 183:2463-2475.

69. Chen P, Ailion M, Bobik T, Stormo G, Roth J: Five promoters integrate control of the cob/pdu regulon in Salmonella typhimurium. J Bacteriol 1995, 177:5401-5410.

70. Ailion M, Bobik TA, Roth JR: Two global regulatory systems (Crp and Arc) control the cobalamin/propanediol regulon of Salmonella typhimurium. Bacteriol 1993, 175:7200-7208.

71. Klumpp J, Fuchs TM: Identification of novel genes in genornic islands that contribute to Salmonella typhimurium replication in macrophages. Microbiology SGM 2007, 153:1207-1220.

72. Heithoff DM, Conner CP, Hentschel U, Govantes F, Hanna PC, Mahan MJ: Coordinate intracellular expression of Salmonella genes induced during infection. J Bacteriol 1999, 181:799-807.

73. Conner CP, Heithoff DM, Julio SM, Sinsheimer RL, Mahan MJ: Differential patterns of acquired virulence genes distinguish Salmonella strains. Proc Natl Acad Sci USA 1998, 95:4641-4645.

74. Bjorkman J, Rhen M, Andersson DI: Salmonella typhimurium cob mutants are not hyper-virulent. FEMS Microbiol Lett 1996, 139:121-126.

75. Stojilikovic I, Baumler AJ, Heffron F: Ethanolamine utilization in Salmonella typhimurium: nucleotide sequence, protein expression, and mutational analysis of the $c \mathrm{ch} A \mathrm{cchB}$ eutE eutJ eutG eutH gene cluster. J Bacteriol 1995, 177:1357-1366.

76. Sperandio V, Torres AG, Kaper JB: Quorum sensing Escherichia coli regulators $B$ and $C$ (QseBC): a novel two-component regulatory system involved in the regulation of flagella and motility by quorum sensing in E. coli. Mol Microbiol 2002, 43:809-821.

77. Goodier Rl, Ahmer BMM: SirA orthologs affect both motility and virulence. J Bacteriol 2001, 183:2249-2258.

78. Teplitski M, Goodier Rl, Ahmer BMM: Pathways leading from BarA/SirA to motility and virulence gene expression in Salmonella. J Bacteriol 2003, 185:7257-7265.

79. Soutourina O, Kolb A, Krin E, Laurent-Winter C, Rimsky S, Danchin A, et al: Multiple control of flagellum biosynthesis in Escherichia coli: role of $\mathrm{H}$ NS protein and the cyclic AMP-catabolite activator protein complex in transcription of the flhDC master operon. J Bacteriol 1999, 181:7500-7508.

80. Shin S, Park C: Modulation of flagellar expression in Escherichia coli by acetyl phosphate and the osmoregulator OmpR. J Bacteriol 1995, 177:4696-4702.

81. Shi WY, Zhou YN, Wild J, Adler J, Gross CA: DnaK, DnaJ, and GrpE are required for flagellum synthesis in Escherichia coli. J Bacteriol 1992, 174:6256-6263.

82. Lehnen D, Blumer C, Polen T, Wackwitz B, Wendisch VF, Unden G: LrhA as a new transcriptional key regulator of flagella, motility and chemotaxis genes in Escherichia coli. Mol Microbiol 2002, 45:521-532.

83. Francez-Charlot A, Laugel B, Van Gemert A, Dubarry N, Wiorowski F, Castanie-Cornet MP, et al: RcsCDB His-Asp phosphorelay system negatively regulates the fIhDC operon in Escherichia coli. Mol Microbiol 2003, 49:823-832.

84. Ellermeier $C D$, Slauch JM: RtsA and RtsB coordinately regulate expression of the invasion and flagellar genes in Salmonella enterica serovar Typhimurium. J Bacteriol 2003, 185:5096-5108. 
85. Bertin P, Terao E, Lee EH, Lejeune P, Colson C, Danchin A, et al: The H-NS protein is involved in the biogenesis of flagella in Escherichia coli. $J$ Bacteriol 1994, 176:5537-5540.

86. Altier C, Suyemoto M, Ruiz Al, Burnham KD, Maurer R: Characterization of two novel regulatory genes affecting Salmonella invasion gene expression. Mol Microbiol 2000, 35:635-646.

87. Hebrard M, Viala JPM, Meresse P, Barras F, Aussel L: Redundant hydrogen peroxide scavengers contribute to Salmonella virulence and oxidative stress resistance. J Bacteriol 2009, 191:4605-4614.

88. Horsburgh MJ, Wharton SJ, Karavolos M, Foster SJ: Manganese: elemental defence for a life with oxygen? Trends Microbiol 2002, 10:496-501.

89. Hacker J, Kaper J: The concept of pathogenicity islands. In Pathogenicity Islands and Other Mobile Virulence Elements. Edited by: Hacker J, Kaper J. Washington, DC: American Society for Microbiology; 1999:1-11.

90. Bowe F, Lipps CJ, Tsolis RM, Groisman E, Heffron F, Kusters JG: At least four percent of the Salmonella typhimurium genome is required for fatal infection of mice. Infect Immun 1998, 66:3372-3377.

91. Hensel M, Nikolaus T, Egelseer C: Molecular and functional analysis indicates a mosaic structure of Salmonella pathogenicity island 2. $\mathrm{Mol}$ Microbiol 1999, 31:489-498.

92. Hensel M: Salmonella pathogenicity island 2. Mol Microbiol 2000, 36:1015-1023.

93. Groisman EA, Ochman $\mathrm{H}$ : Cognate gene clusters govern invasion of host epithelial cells by Salmonella typhimurium and Shigella flexneri. EMBO J 1993, 12:3779-3787.

94. Shea JE, Hensel M, Gleeson C, Holden DW: Identification of a virulence locus encoding a second type III secretion system in Salmonella typhimurium. Proc Natl Acad Sci USA 1996, 93:2593-2597.

95. Collazo CM, Galan JE: The invasion-associated type III system of Salmonella typhimurium directs the translocation of Sip proteins into the host cell. Mol Microbiol 1997, 24:747-756.

96. Ochman H, Groisman EA: Distribution of pathogenicity islands in Salmonella spp. Infect Immun 1996, 64:5410-5412.

97. Deiwick J, Nikolaus T, Erdogan S, Hensel M: Environmental regulation of Salmonella pathogenicity island 2 gene expression. Mol Microbiol 1999, 31:1759-1773.

98. Chan K, Kim CC, Falkow S: Microarray-based detection of Salmonella enterica serovar Typhimurium transposon mutants that cannot survive in macrophages and mice. Infect Immun 2005, 73:5438-5449.

99. Lawley TD, Chan K, Thompson LJ, Kim CC, Govoni GR, Monack DM: Genome-wide screen for Salmonella genes required for long-term systemic infection of the mouse. PLOS Pathog 2006, 2:e11.

100. Yoon H, Lim S, Heu S, Choi S, Ryu S: Proteome analysis of Salmonella enterica serovar Typhimurium fis mutant. FEMS Microbiol Lett 2003 226:391-396.

101. Wilson RL, Libby SJ, Freet AM, Boddicker JD, Fahlen TF, Jones BD: Fis, a DNA nucleoid-associated protein, is involved in Salmonella typhimurium SPI-1 invasion gene expression. Mol Microbiol 2001, 39:79-88.

102. Sheikh J, Hicks S, Dall'Agnol M, Phillips AD, Nataro JP: Roles for Fis and YafK in biofilm formation by enteroaggregative Escherichia coli. Mol Microbiol 2001, 41:983-997.

103. Schmitt CK, Ikeda JS, Darnell SC, Watson PR, Bispham J, Wallis TS, et al: Absence of all components of the flagellar export and synthesis machinery differentially alters virulence of Salmonella enterica serovar Typhimurium in models of typhoid fever, survival in macrophages, tissue culture invasiveness, and calf enterocolitis. Infect Immun 2001 69:5619-5625.

104. Schechter LM, Jain S, Akbar S, Lee CA: The small nucleoid-binding proteins $\mathrm{H}-\mathrm{NS}, \mathrm{HU}$, and Fis affect hilA expression in Salmonella enterica serovar Typhimurium. Infect Immun 2003, 71:5432-5435.

105. Goldberg MD, Johnson M, Hinton JCD, Williams PH: Role of the nucleoidassociated protein Fis in the regulation of virulence properties of enteropathogenic Escherichia coli. Mol Microbiol 2001, 41:549-559.

106. Falconi M, Prosseda G, Giangrossi M, Beghetto E, Colonna B: Involvement of Fis in the H-NS-mediated regulation of virF gene of Shigella and enteroinvasive Escherichia coli. Mol Microbiol 2001, 42:439-452.

doi:10.1186/1471-2180-11-58

Cite this article as: Evans et al:: Analysis of the ArcA regulon in anaerobically grown Salmonella enterica sv. Typhimurium. BMC Microbiology 2011 11:58.

\section{Submit your next manuscript to BioMed Central and take full advantage of:}

- Convenient online submission

- Thorough peer review

- No space constraints or color figure charges

- Immediate publication on acceptance

- Inclusion in PubMed, CAS, Scopus and Google Scholar

- Research which is freely available for redistribution 